\title{
Seismic-Scale Evidence of Thrust-Perpendicular Normal Faulting in the Western Outer Carpathians, Poland
}

\author{
Jan Barmuta ${ }^{1, *}$, Krzysztof Starzec ${ }^{2}$ and Wojciech Schnabel ${ }^{3}$ \\ 1 Department of Fossil Fuels, Faculty of Geology, Geophysics and Environmental Protection, AGH University \\ of Science and Technology, 30-059 Kraków, Poland \\ 2 Department of General Geology and Geotourism, Faculty of Geology, Geophysics and Environmental \\ Protection, AGH University of Science and Technology, 30-059 Kraków, Poland; kstarzec@agh.edu.pl \\ 3 Geokrak Ltd., 30-019 Kraków, Poland; wojciech.schnabel@geokrak.pl \\ * Correspondence: jbarmuta@agh.edu.pl; Tel.: +48-604-513-490
}

check for updates

Citation: Barmuta, J.; Starzec, K.; Schnabel, W. Seismic-Scale Evidence of Thrust-Perpendicular Normal Faulting in the Western Outer Carpathians, Poland. Minerals 2021, 11, 1252. https://doi.org/10.3390/ $\min 11111252$

Academic Editor: Neil M. Ribe

Received: 10 September 2021

Accepted: 8 November 2021

Published: 11 November 2021

Publisher's Note: MDPI stays neutral with regard to jurisdictional claims in published maps and institutional affiliations.

Copyright: (c) 2021 by the authors. Licensee MDPI, Basel, Switzerland. This article is an open access article distributed under the terms and conditions of the Creative Commons Attribution (CC BY) license (https:/ / creativecommons.org/licenses/by/ $4.0 /)$.

\begin{abstract}
Based on the interpretation of 2D seismic profiles integrated with surface geological investigations, a mechanism responsible for the formation of a large scale normal fault zone has been proposed. The fault, here referred to as the Rycerka Fault, has a predominantly normal dipslip component with the detachment surface located at the base of Carpathian units. The fault developed due to the formation of an anticlinal stack within the Dukla Unit overlain by the Magura Units. Stacking of a relatively narrow duplex led to the growth of a dome-like culmination in the lower unit, i.e., the Dukla Unit, and, as a consequence of differential uplift of the unit above and outside the duplex, the upper unit (the Magura Unit) was subjected to stretching. This process invoked normal faulting along the lateral culmination wall and was facilitated by the regional, syn-thrusting arc-parallel extension. Horizontal movement along the fault plane is a result of tear faulting accommodating a varied rate of advancement of Carpathian units. The time of the fault formation is not well constrained; however, based on superposition criterion, the syn -thrusting origin is anticipated.
\end{abstract}

Keywords: seismic interpretation; western outer carpathians; hanging-wall drop fault; orogen parallel extension; syn-thrusting normal faulting

\section{Introduction}

The Outer Carpathians (OC) are a well-known example of a thrust and fold belt formed during the Alpine orogeny as a result of the Alpine-Carpathian (Alcapa) and the Tisa blocks collision with the North European Platform (e.g., [1-3]). This young, Miocene in age, thrust and fold belt encircles inner units and forms an arcuate geometry, (e.g., [1,4,5]). The structural fabric of the Outer Carpathian, i.e., main thrusts and folds, follows the arcuate geometry. The geometry of the Outer Carpathians Thrust and Fold Belt (OCTFB) implies the occurrence of a radial (i.e., arc-parallel) extension at least in the outer part of this mountain arc. It is assumed that the effects of such forces should be recorded as extension-related structures like roughly thrust-perpendicular normal faults. Such structures were comprehensively studied for example in the area of Alps (e.g., Simplon and Brenner faults) [6-9].

Apart from the compression-related structures, numerous normal and strike-slip faults were described in the OC. Based on his research, Unrug [10] provided a general description of regional-scale, thrust-perpendicular, strike-slip faults identified along the arc of the Polish Outer Carpathians and claimed their syn-thrusting origin. Aleksandrowski [11] suggested that thrust-orthogonal faulting, mainly of tear-fault character, occurred during the compressional phase. The author stressed the different development of folds on both sides of such faults, which exclude their post-compressional origin. Using the palinspastic restoration method, Morley [12] proved that the arc-parallel extension related to the arcuate 
nature of the OCTFB is a must, and should be compensated by the transtensional faults. Based on field studies from the eastern part of the Polish OC, Rubinkiewicz [13] linked the normal faulting events with the post-orogenic uplift of the Carpathians. The first event was characterized by a minimum stress axis $(\sigma 3)$ being approximately orthogonal to the thrusting direction, which resulted in normal faulting perpendicular to the thrusts. During the second stage, because of the reorientation of the stress axis, normal faults' strikes aligned with the thrusts. Jankowski and Margielewski [14] emphasized the significance of the gravitational collapse of the Carpathian orogen, as well as its syn-compressional radial extension in the formation of normal faults. According to the authors, the latter process was responsible for the formation of a set of normal faults that are roughly perpendicular to the strike of main compressional tectonic features. Such faults are drawn on recent geological maps co-authored by Jankowski [15]. In the paper by Jankowski [16], the author presents numerous examples of normal faults observed in outcrops, implying gravitational collapse and radial extension as the main processes responsible for their formation. However, no clear criteria were presented on how these kinds of faults might be identified. Jankowski's view corresponds to the results of other researches. For example, based on thermochronology supported by cross-section restoration it was proved that the extensional regime is related to the late Miocene exhumation of the orogen and its gravitational readjustment [17-20]. In numerous articles authored by Zuchiewicz [21-23], it is suggested that the neotectonic activity of the Outer Carpathians is related to the post-thrusting relaxation of the horizontal compressional stress, as well as to the isostasy. In subsequent paper, Zuchiewicz and co-authors [24] gave an extensive overview of the recent (from the late Miocene to the present day) stress regime evolution of the Carpathian Fold and Thrust Belt. In this paper, the authors suggest that during the late Neogene times, the Polish part of the OC was shaped mainly by normal faulting episodes. However, they also underline that during that time some compression related structures were also formed, therefore it can be assumed that non-uniform stress arrangement within the Polish Outer Carpathians is possible. For the Pliocene to Quaternary period, a weak, thin-skinned tectonics is postulated by the authors. During this period, some normal faulting occurred at the margins of intramontane basins as well as in the western part of the fold-and-thrust belt.

The evolution and strain patterns of arcuate mountain belts had been widely investigated based on theoretical considerations, analogue and digital modelling, paleomagnetic and magnetic susceptibility investigations as well as field examples (e.g., [6-8,12,25-40]). Hindle and Burkhard [34] summarized most of the proposed models and distinguished three end-members of arcuate mountain belts, i.e., oroclines, "piedmont glaciers" and primary arcs. According to their definition, oroclines are formed as a result of the pure bending of initially straight belts. This model requires a large amount of extension along the outer side of an arc and compression in the inner part. The "piedmont glacier" model also exhibits significant arc-parallel extension related to radially divergent transport directions [29]. In this model, the amount of extension increases towards the foreland. In contrast to the previous models, primary arcs are characterized by uniform transport directions and exhibit arcuate geometry from the beginning of formation. They can be discriminated from previous models by significantly lower rates of the radial extension. Not without importance is a thin- or thick-skinned character of an arc. Johnston and co-authors [37] differentiate between progressive and secondary arcs which are a product of thin- or thick-skinned tectonics, respectively. According to the authors, progressive arcs (thin-skinned) are characterized by a much lower degree of radial extension with respect to secondary arcs (thick-skinned), which formation involves the upper mantle. 
Despite the ambiguous origin of the OCTFB in terms of formation of the arc [12,32,41-47], a considerable amount of extension is expected within nappes units. According to Zweigel and co-authors $[45,46]$ the magnitude of radial extension in the Romanian sector of the Outer Carpathians does not exceed 20\%. Slightly higher values, up to $26 \%$, are suggested from map-based restorations performed by Morley [12]. Despite no direct estimations of the magnitude of the radial extension for the Polish sector of the OCTFB, geological maps depict numerous normal and strike-slip faults perpendicular or oblique to the thrusts (e.g., $[15,48,49])$ suggesting the radial extension as a process responsible for their formation $[14,50]$. This view is also supported by meso- and microscale structural observations $[13,46,49]$. The syn-compressional normal fault pattern is overprinted by normal faults formed during the post-thrusting extension event mainly of orogen-normal character $[14,24]$. This concept is supported by the apatite fission track analysis [17-20] indicating extension-related exhumation and gravitational collapse of the accretionary wedge. Extensive field investigations with a detailed analysis of kinematic indicators performed by Beidinger and Decker [51] in the area of the NE Slovakia and SW Czech Republic demonstrate that the western OC were deformed in four deformation phases, which can be directly correlated with the tectonic history of the Eastern Alps.

In this article, based on seismic data interpretation, geological mapping and highresolution digital elevation model (DEM) analysis supported by field observations, we describe a seismic-scale, thrust-perpendicular fault, here referred to as the Rycerka Fault (RF). We identify and investigate the link between the formation of an anticlinal stack in the Dukla Unit and the nucleation of the Rycerka Fault. Finally, we attempted to explain the formation of the RF in the context of the evolution of the OCTFB and demonstrate that arc-parallel extension might be an important factor responsible for the formation of large-scale (i.e., hundreds to thousands meters displacement), normal faults.

\section{Geological Settings}

The research area is located in the westernmost part of the Polish Outer Carpathians which are composed of large thrust sheets encircling the inner part of the Carpathian orogen, (e.g., [1,52]) (Figure 1). The formation of these thrust sheets, also referred to as nappes, was related to the Miocene closing of several sedimentary basins, which previously had been developed on the thinned crust of the European Platform [1-4,53]. During the thrusting phase, the sedimentary fill of the basins was detached and thrusted northward onto the North European Platform, therefore each nappe is expected to represent a sedimentary fill of a different basin or its part. Within the Polish segment of the Outer Carpathians, the following units have been recognized (from south to north) (Figure 1): the Magura Unit, the Dukla Unit and the Fore-Magura Group of Units, the Silesian and sub-Silesian Units and the Skole Unit, which is known to occur only in the eastern and central parts of the Polish OC. The Dukla Unit was originally defined in the eastern part of the Polish OC [54], whereas deposits cropping out in the central and western OC in the form of several elongated tectonic windows or semi-windows within the Magura Unit were recognized as the Fore-Magura units [55]. Nevertheless, the same structural position and similarity in sedimentary succession imply that the Fore-Magura units form the western extension of the Dukla Unit [56,57] (Figure 1). 


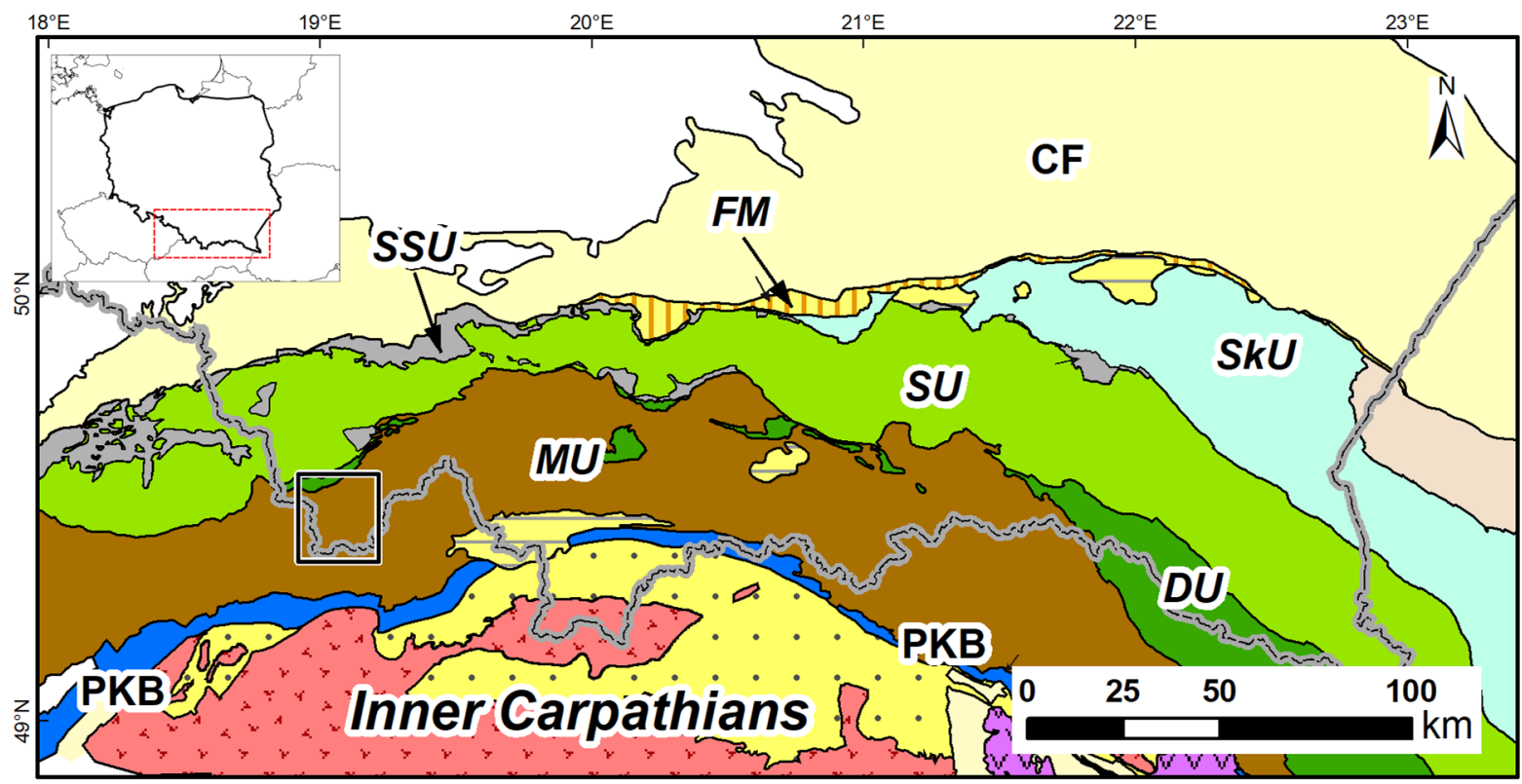

Figure 1. Schematic map of the Polish Outer Carpathians. Research area marked with a black rectangle (see Figure 3). PKB-Pieniny Klippen Belt (tectonic suture zone between the Outer and Central Western Carpathians of thrust and strike-slip origin, represented by the Jurassic-Lower Cretaceous shallow to deep-water limestones), MU-Magura Unit (the innermost and largest tectonic unit of the Western Outer Carpathians, built of the Upper Cretaceous and Paleogene flysch-type sediments), DU—Dukla Unit (structurally lower unit, composed of the Upper Cretaceous and Paleogene preand synorogenic flysch-type sediments), SU—Silesian Unit (composed of continuous succession of the Upper Jurassic to Lower Miocene deposits, with predominance of pre-orogenic flysch deposits in the western part and syn-orogenic in the east), SSU—Sub-Silesian Unit (tectonically underlying the Silesian Nappe, composed mostly of the Upper Cretaceous to Eocene pelagic variegated marls, deposited on the intrabasinal Sub-Silesian ridge forming the northern slope of the Silesian Basin), SkU—Skole Unit (most external unit of the Polish Outer Carpathians, built of the Lower Cretaceous to Miocene rock succession with predominance of syn-orogenic Oligocene to Miocene deposits), CF-Carpathian Foredeep (molasses-type sediments), FM-Folded Miocene sediments of Carpathian Foredeep (para-autochthonous). See text for more explanations.

The research area is occupied by the sedimentary sequence belonging to the Magura Unit (Figure 1), which is divided into four second-order sub-units (from south to north): the Krynica, Bystrica, Rača and Siary Subunit [58]. However, only the last two subunits are present in the research area. Within the research area, the Magura Unit is built of the Upper Cretaceous to Oligocene rocks formed as a result of deep water, flysch-like sedimentation [59,60] (Figures 2 and 3). The oldest shaly Malinowa Formation of the Turonian-Lower Senonian age forms part of the Siary Subunit [61,62]. Above, a thick turbidite sequence of the Jaworzynka Formation, Szczawina Formation and Ropianka Formation [62-66], formerly known collectively as the Inoceramian Beds [67] is present. These formations represent the Upper Cretaceous to Palaeocene period. At the end of the Palaeocene, the deposition of the deep-water variegated shales of the Łabowa Shale Formation occurred throughout the whole Magura Basin [68]. This kind of sedimentation continued into Eocene; however, in the south parts (the Bystrica Sub-unit and the Rača Sub-unit) it was replaced by the Beloveza Formation dominated by thin-bedded turbidites [62,69]. The youngest deposits are represented by the Magura Formation in the Bystrica and Rača Sub-units and by the Zembrzyce Formation known from the Siary Sub-unit. 


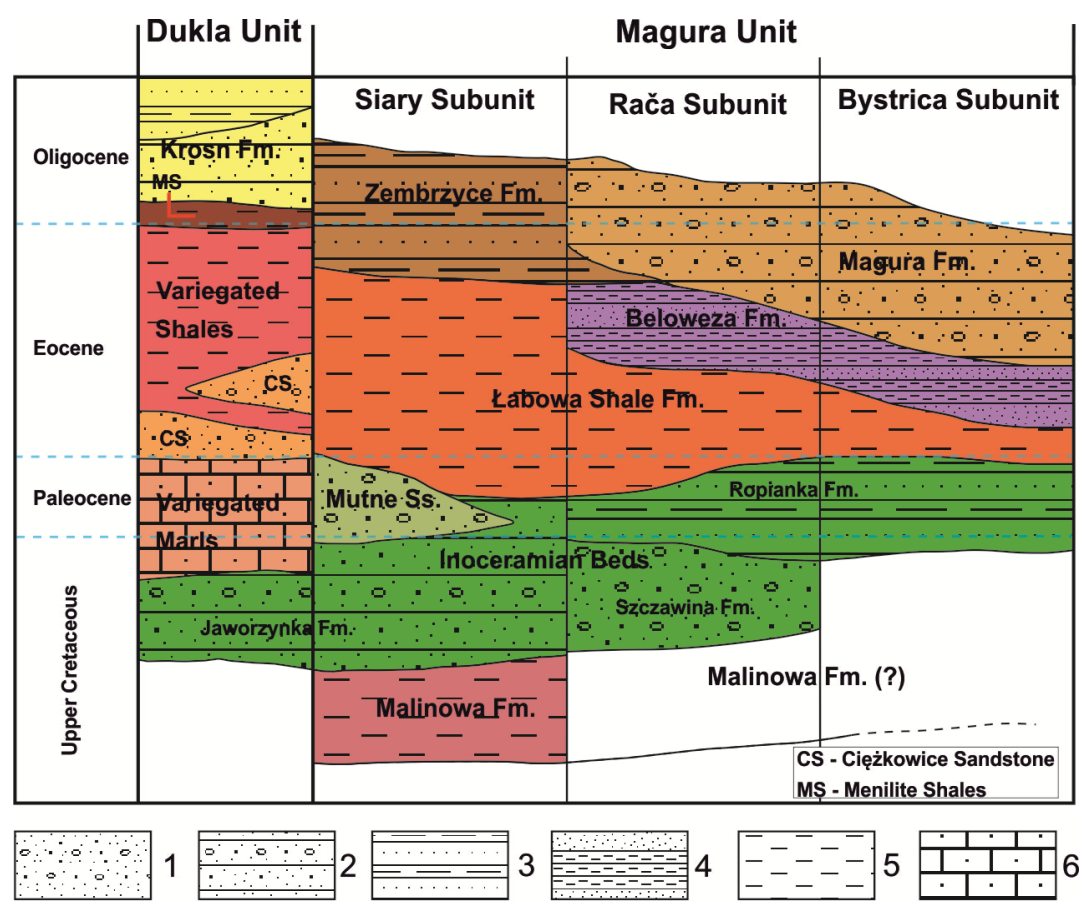

Figure 2. Simplified lithostratigraphic scheme of the Magura and Fore-Magura Units. 1-mainly thick-bedded sandstones and conglomerates, 2-thick-bedded sandstones, subordinately conglomerates, interbedded by thin shales, 3-thick to medium bedded sandstones and shales, 4-shales and thin to medium bedded sandstones, 5-shales, subordinately thin-bedded sandstones, 6-marls (modified after [70]).

The Dukla Unit forms a narrow strip in front of the Magura Unit (Figure 3). Within the research area, mainly the youngest formation crop out, i.e., the Krosno Formation and the Menilite Beds (Figure 2). The Krosno Formation is traditionally divided into three members, i.e., the Lower, Middle and the Upper Krosno Beds, differing in sandstone to mudstones proportions. However, in the investigated area only two distinctly different members are present, i.e., thick-bedded sandstones with scarce thin mudstone intercalations which correspond to the Lower Krosno member, and the Upper Krosno member dominated by thin-bedded mudstones with subordinate amount of sandstone layers. The area north of the Dukla Unit is built from a continuous sequence of the uppermost Jurassic to Oligocene rocks reaching c.a $5.4 \mathrm{~km}$ in thickness [71], which structurally belongs to the Silesian Unit. In general map view, the sedimentary sequence of the Silesian Unit forms a southdipping homocline.

According to geological maps, the Magura Unit displays a relatively complex geometry. It is deformed internally by numerous second-order thrusts and thrust related folds, both of which are characterized by WSW-ENE strikes and segmented by NNW-SSE trending faults (Figure 3). Thrust-related folds are asymmetric and tend to have steep and in most cases overturned layers in the forelimb (the northern side of the folds). In the axial zone of the folds and their forelimbs the Upper Cretaceous and Palaeocene rocks display a map pattern characterized by relatively narrow belts. Layers forming the backlimbs dip more gently and comprise a more complete stratigraphic sequence up to the Oligocene Magura Formation, which is the most prominent component of these limbs (Figures 2-4). 


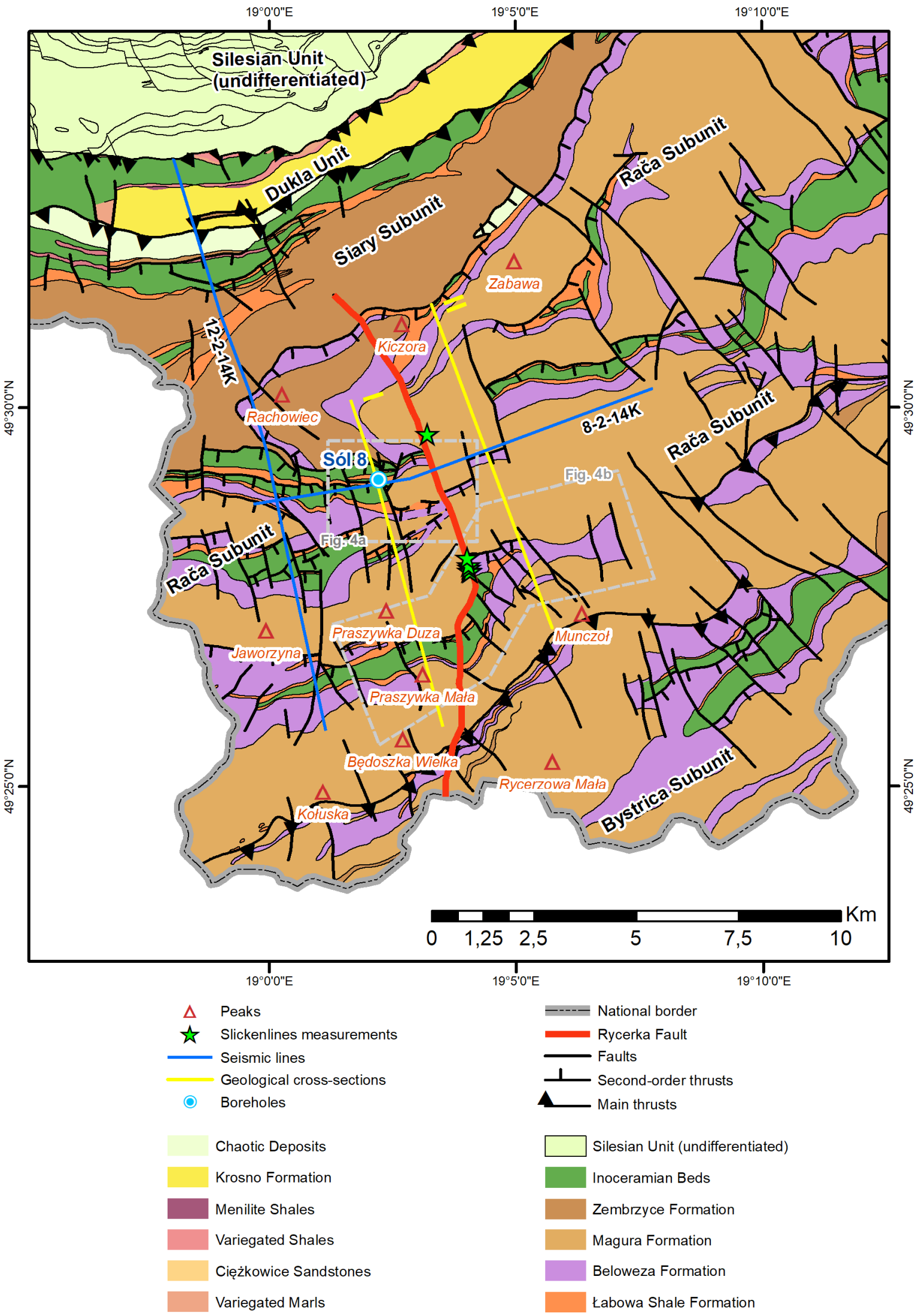

Figure 3. Detailed geological map of the research area (after [71], modified). 12-2-14K and 8-2-14K-seismic profiles presented in Figures 13 and 14. Zones marked with gray-dasked polygons are shown in subsequent figure. Green stars-outcrops with measurements used for stress inversion. 

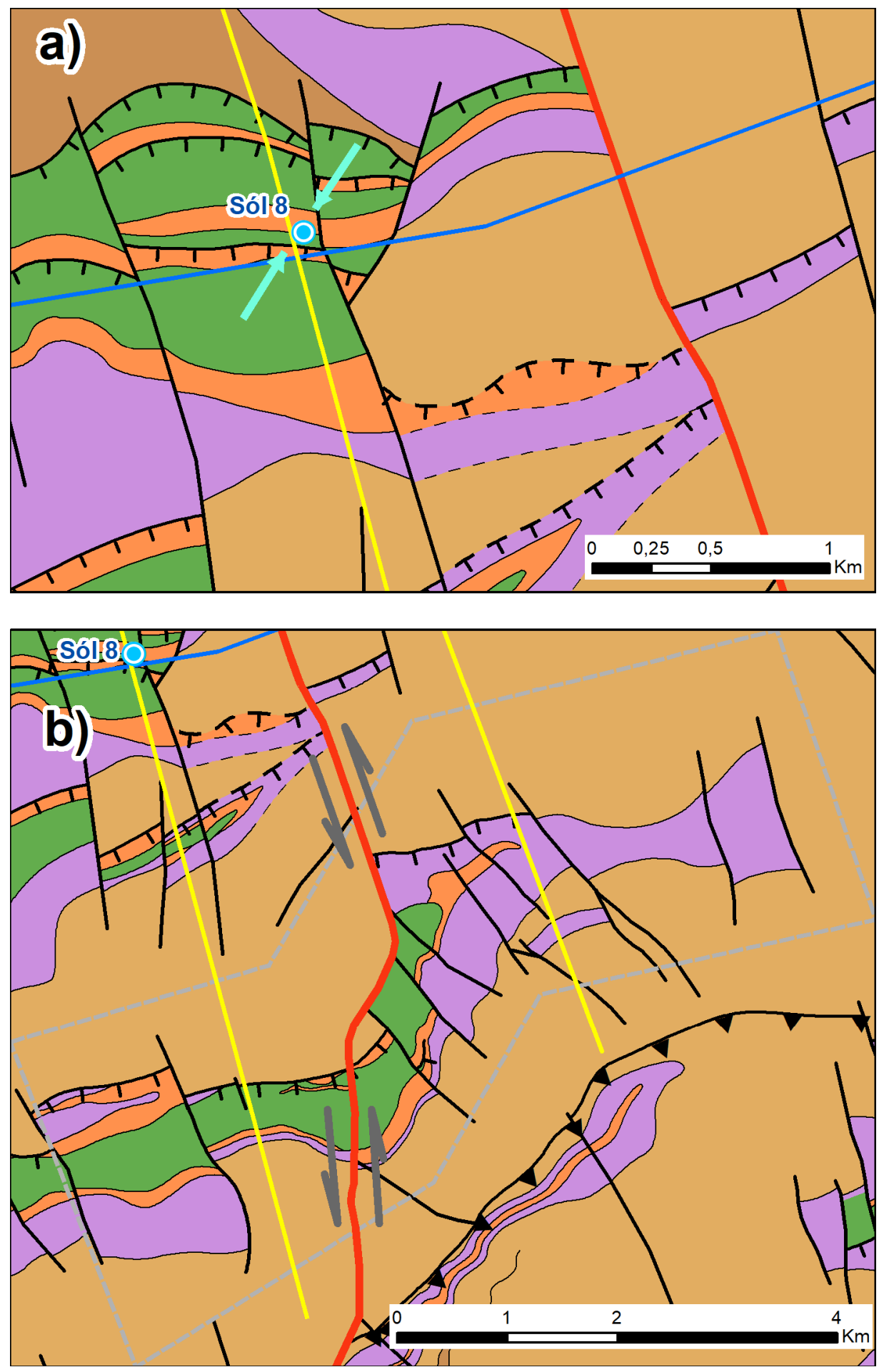

Figure 4. (a) Location of the Sól-8 borehole with the approximate direction of the $\mathrm{Sh}_{\max }$ after Jarosiński marked by arrows, (b) bending of the anticline axis indicating sinistral displacement on the Rycerka Fault.

\section{Data and Methods}

\subsection{Surface Data}

The surface data were collected during detailed mapping campaigns encompassing the westernmost part of the Polish Outer Carpathians. A classic surface geological mapping, including a standard macroscopic description of outcrops as well as stratigraphic and structural observations, with the use of modern techniques (GPS receiver by Garmin, 
Olathe, Kansas, US; ArcGIS software by ESRI, Redlands, CA, US), was conducted. The archival, open-access, 1:50,000 scale geological maps were used in the map updating process [72-74]. As a result, a 1:25,000 scale map was prepared (Figure 3) [71]. The fieldwork was extended and complemented by using remote sensing data as orthophotomaps and LiDAR-derived digital elevation model (DEM). These data were acquired from the Polish national geodetic and cartographic resource. Especially, the last data were significantly helpful and allowed for accurate mapping of structural features in the densely forested study area.

Additionally, for the sake of this investigation, 28 measurements of slickenlines and faults' planes were collected in outcrops located along the RF (Figure 3). Twenty-three measurements were used for a stress inversion procedure. The remaining 5 five measurements were rejected due to their incongruent character. It is assumed that they might be erroneously measured or represent different tectonic phases. The stress inversion was performed using the Stress Analysis Tool available in Move software. As a result, the orientation of principal stresses and shape ratio were calculated (Figure 5). The obtained stress field points to the normal faulting regime with negligible strike-slip component as suggested by the shape ratio equals 0.49 . The $\mathrm{S} 1$ is almost vertical, while the plunge azimuth of the $\mathrm{S} 2\left(\mathrm{Sh}_{\max }\right)$ is $34.3^{\circ}$ (NNE). The results of the stress inversion are in agreement with breakout analysis in the Sól-8 borehole (see below).

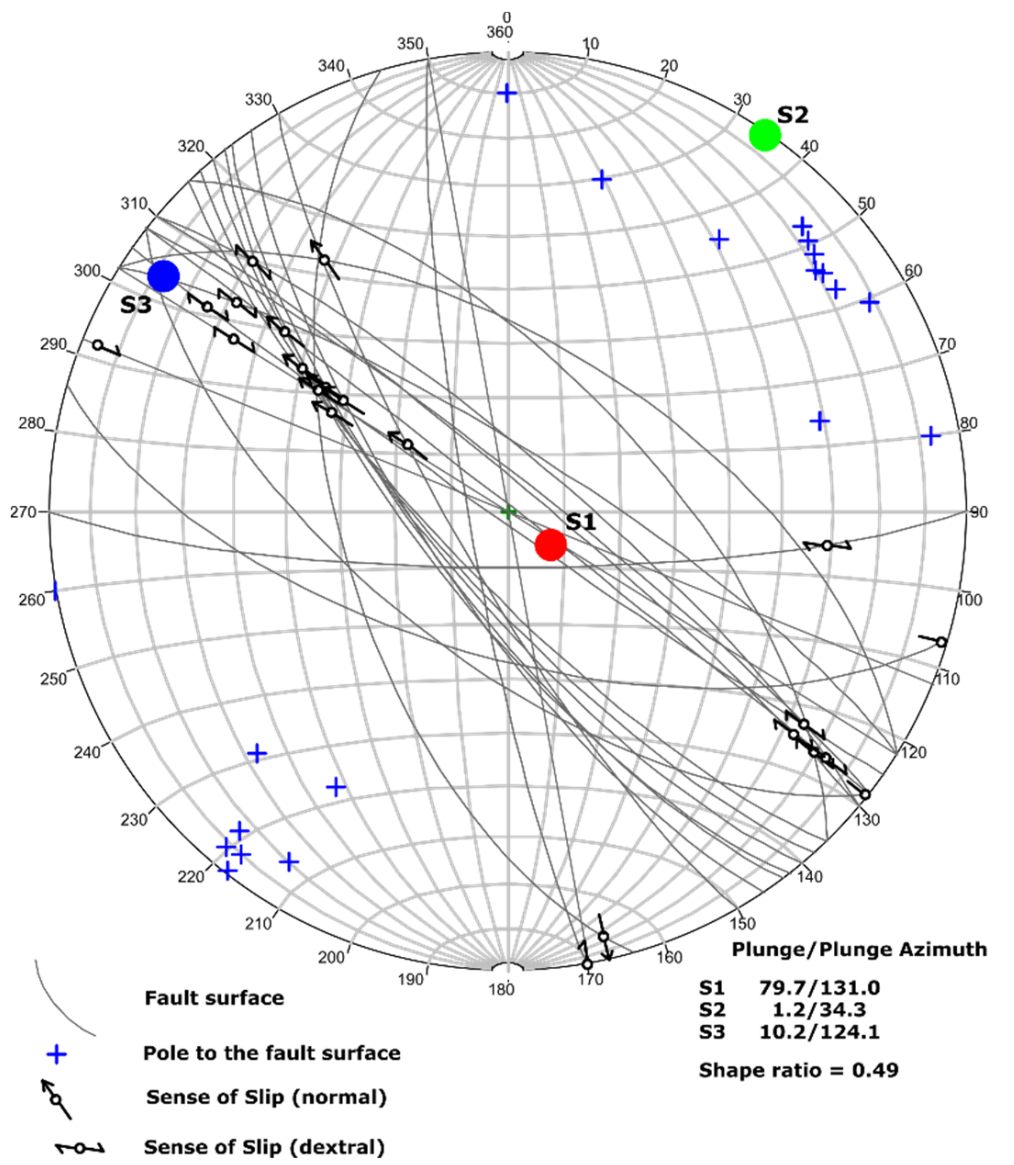

Figure 5. Results of the stress inversion. S1, S2, S3-principal stresses (S1 > S2 > S3).

\subsection{Well Data}

Although, several exploratory wells have been drilled within the study area, only data coming from Sól-8 were available. The Sól-8 well was drilled in 1994 and reached $2000 \mathrm{~m}$ MD (Measured Deapth) (Figure 6). It is located in the northern limb of the Sól anticline which forms the frontal zone of the Rača Subunit. The well drilled through deposits of the Magura Unit and terminated in the sedimentary sequence of the Dukla Unit. The 
stratigraphy of the Dukla Unit is not well recognized. Within this sequence, at least three minor thrusts were identified. In the bottommost part of the well, fine-grained glauconitic sandstones were reached. They were originally interpreted as the Godula Formation of the Silesian Unit, although their assignment to this formation is highly ambiguous. Recently, based on cuttings descriptions, results of wells located more to the east of the studied area (i.e., Obidowa IG1 and Chabówka 1 [75]) and recently acquired seismic data, these sandstones have been reinterpreted by the authors as the Inoceramian Beds representing the lower part of the Dukla Unit succession [71,76].

Breakouts analysis for Sól-8 well was performed by Jarosiński $[77,78]$. The author noticed breakouts only in the 400-700 MD interval and indicated the NNE-SSW direction of the $\mathrm{Sh}_{\max }$, precisely $29^{\circ} \pm 18^{\circ}$ or $34^{\circ} \pm 19^{\circ}$ according to Jarosiński [77] or Jarosiński [78], respectively (Figure 6).

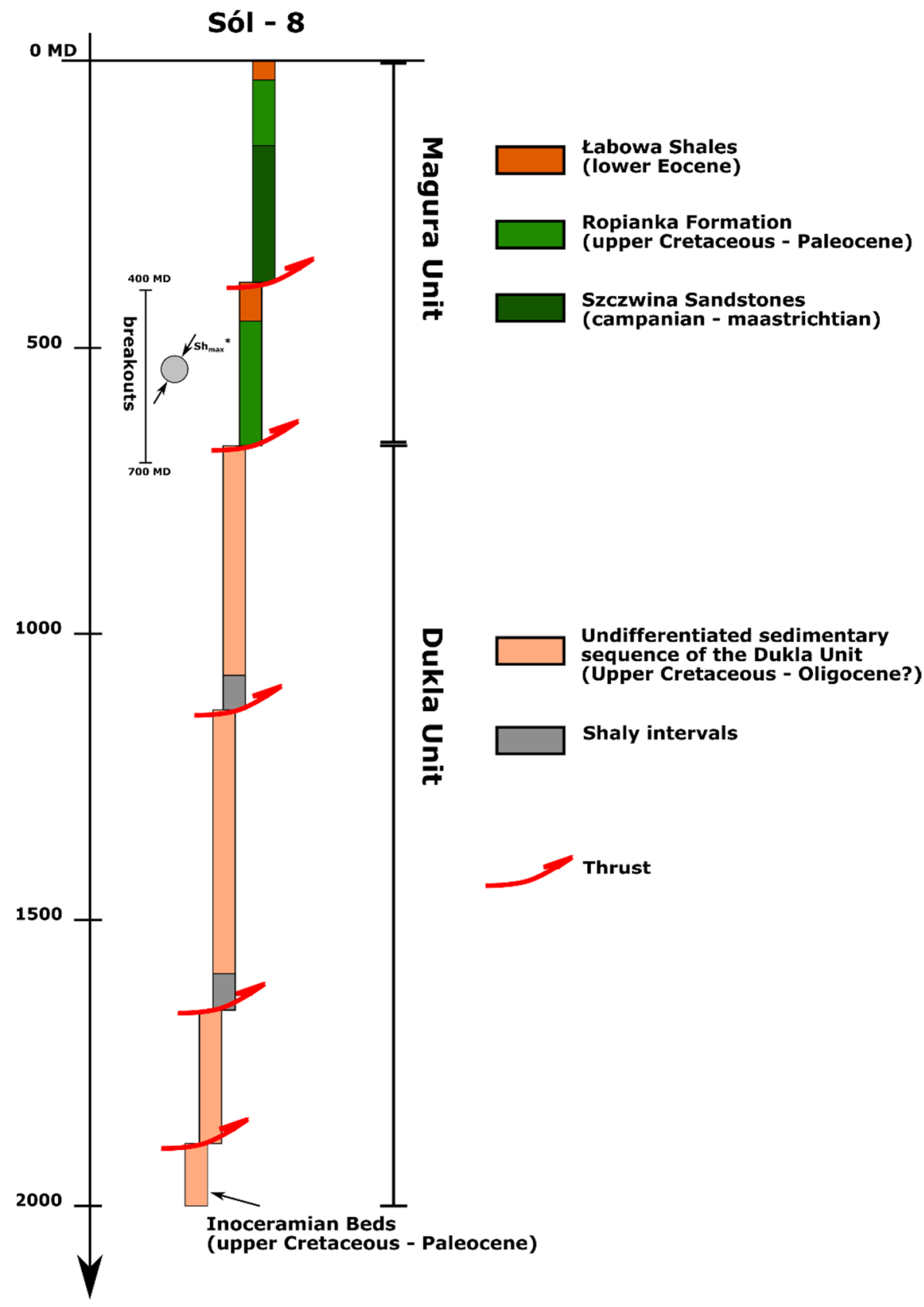

Figure 6. Stratigraphic profile of the Sól-8 borehole with simplified stratigraphic profile and thrust faults identified. *-approximate direction of the $\mathrm{Sh}_{\max }$ based on $[77,78]$. 


\subsection{Seismic Data}

The presented 8-2-14K and 12-2-14K seismic profiles were acquired during the seismic survey campaign in 2014 (Figure 2). The acquisition array assumed shot points and receivers spacing equal to be $40 \mathrm{~m}$ and $20 \mathrm{~m}$, respectively. The maximum recorded offset was $5000 \mathrm{~m}$. The explosive source ( $2 \mathrm{~kg}$ dynamite) was used to induce the acoustic wave. Due to the difficult terrain conditions, numerous shot points and receiver points were omitted which strongly affect seismic data quality. High amplitude surface waves and shallow refractions are the most prominent features visible on raw shot gathers. These features mask the useful signal and make processing difficult and ambiguous. For best results, the seismic data were processed in three versions, i.e., Post Stack Time Migration (PostSTM), Pre Stack Time Migration (PreSTM) and Pre Stack Depth Migration (PreSDM). Due to the ambiguities encountered during the processing phase, a preliminary interpretation was carried out at each stage to guide and verify the results of the processing. The PreSDM version of the processed seismic data gave the best structural imaging results, therefore it was selected for final interpretation.

\section{Results}

\subsection{Surface Expression of the Rycerka Fault (RF)}

The RF divides the Rača Subunit into two parts and it continues northward into the Siary Subunit. It intersects the subunits in direction almost perpendicular to main thrusts. The differences between the west and east sides of the RF, in terms of their tectonic structure and lithostratigraphic units, are especially noticeable within the first subunit (Figures 3 and 7).

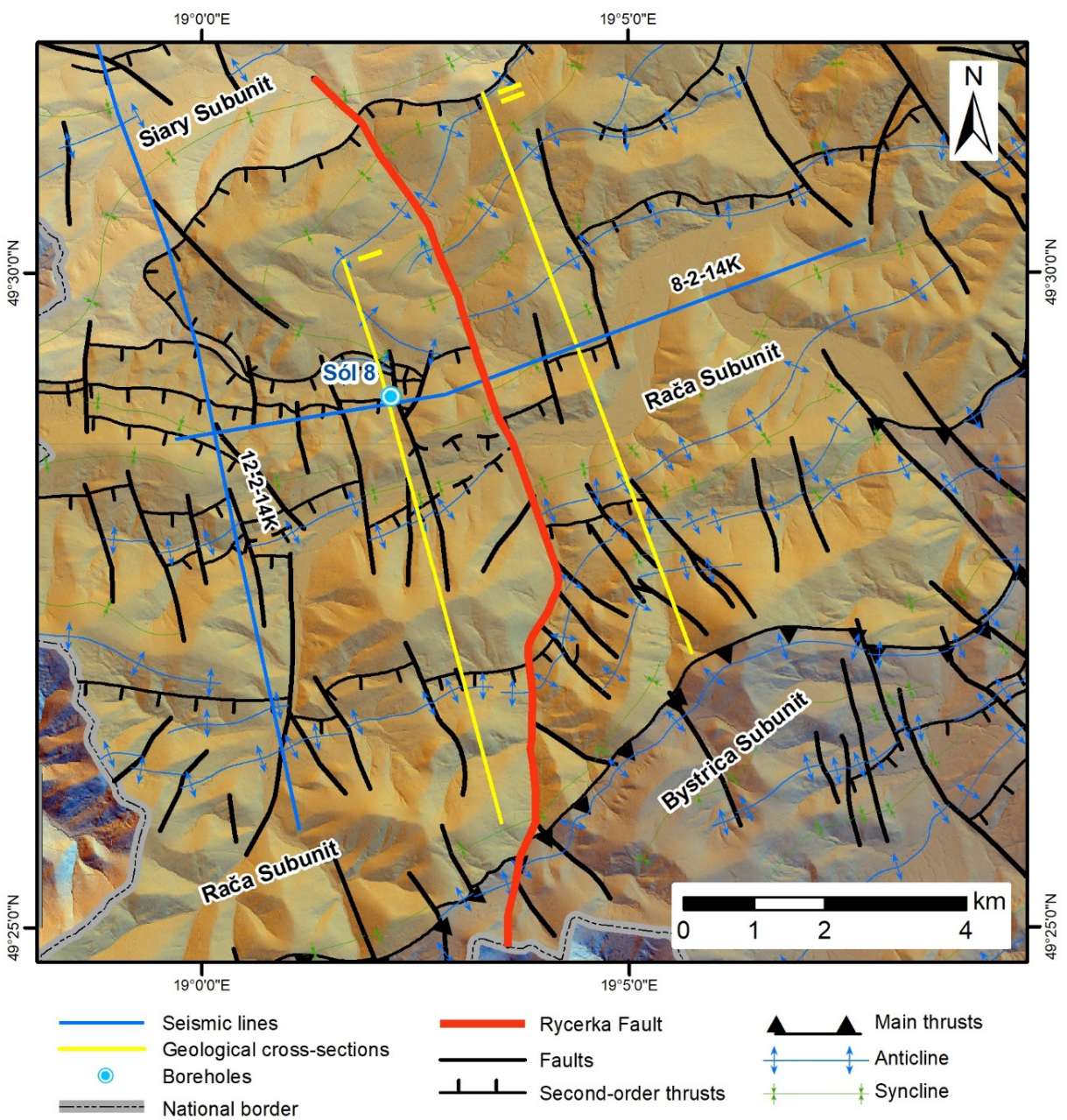

Figure 7. Structural maps of the investigated area displayed on top of the DEM. 
The structure of the western side of the RF involves several north-vergent thrust related folds (thrust sheets) (Figures 3 and 7), in which the forelimbs are composed of the oldest lithostratigraphic units known from the Rača Subunit, i.e., the Upper Cretaceous Szczawina and Ropianka formations (see Figure 2). They are exposed along a relatively broad strip forming an axial part of the thrust sheets. Thrust faults within these structures change laterally in some segments being developed directly within the Cretaceous formations, whereas in other segments, the sole thrust is located within the Palaeocene to Eocene Łabowa and Beloveza formations. These formations usually display complex deformations at the scale of outcrop with small-scale folds and internal thrusts. In folds' hinge zones the Cretaceous formations are brecciated, which resulted in their block-in-matrix fabric, where sandstone blocks of different sizes are randomly distributed in a muddy-sandy matrix (Figure 8a) [79-83]. However, in such rock complexes, the primary strata sequence can be still recognized and thicker layers dip to the south reflecting the general inclination of the thrust structure (Figure $8 \mathrm{~b}$ ). Within the backlimbs of the thrust related folds, the complete sequence of the Raca Unit is usually preserved. Field sections observed along the river beds expose regularly bedded rocks that are younger in the south, i.e., the Cretaceous deposits outcropping in the hinge zone passes through the Palaeocene-Eocene red shales of Łabowa Fm and the Eocene thin-bedded sandstones and shales of the Beloveza Formation to a complex consisting mainly thick-bedded sandstones representing the youngest Magura Formation. In the outcrops, backlimb sequence is characterized by almost homoclinal geometry with only slight internal deformations limited to the incompetent thin-bedded deposits of Paleocene and Eocene age, whereas layers of the Magura Fm. sandstone complex maintain similar strike and dip, with little variations in dip angle (Figure 9).
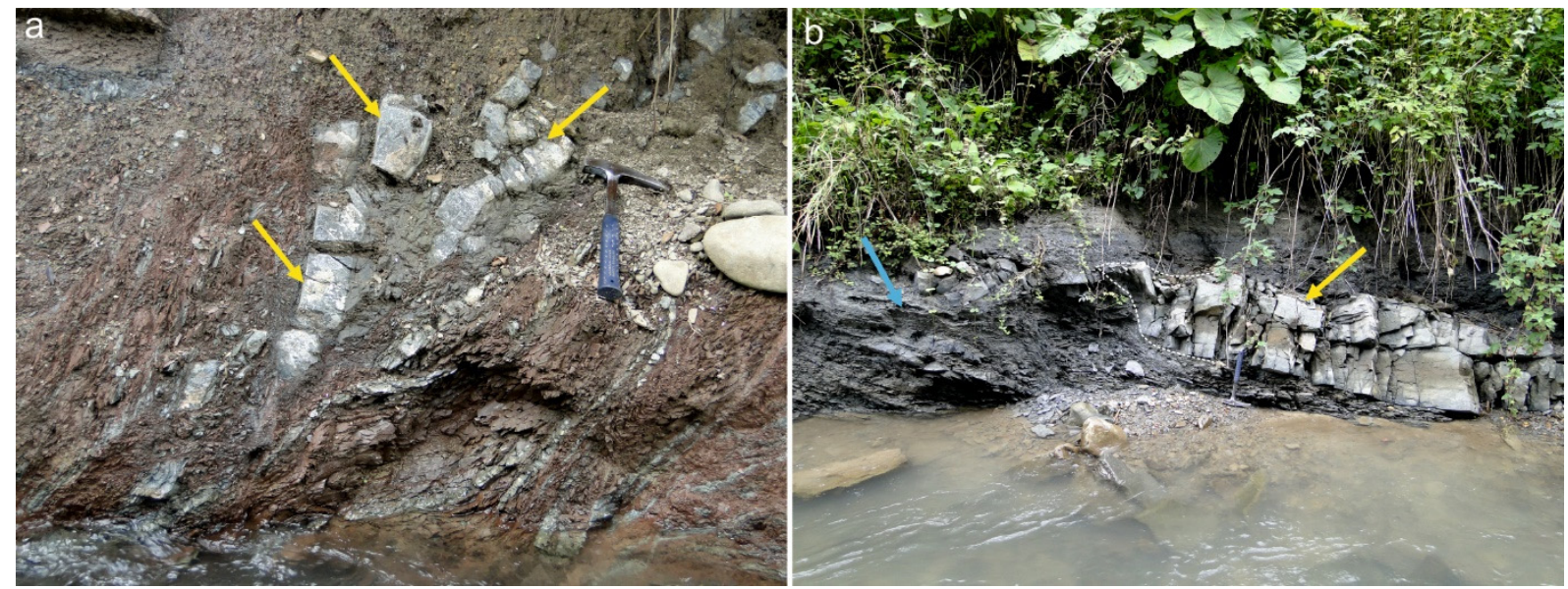

Figure 8. Deformed rocks at the hinge zone of the thrust related fold in the Rača Unit: (a) disrupted fragments of thin sandstone layers (indicated by arrows) randomly included in the greenish-red shaly matrix, (b) grey shaly matrix (blue arrow) enclosing a fractured sandstone block (yellow arrow) preserving dip direction and dip angle similar to the dip of the fold limb.

The structural style of the eastern side of the RF differs significantly. First of all, most of the Rača Unit thrust structures, which are visible on the western side, do not continue to the east of the RF. Only the thrust sheet that forms the southernmost part of the Unit extends to the east side of the fault (Figure 3). However, the plan-view reveals the sigmoidal pattern of this sheet. The strike of this structure changes from NE-SW direction in the western area to NNE-SSW at the fault zone, and revert to the previous orientation on the eastern side of the RF, which is reflected also in the topography of the area (Figure 7). Based on the shape bending of the fold axis the sinistral movement along the fault plane can be inferred (Figures 3, $4 \mathrm{~b}$ and 7). The contrast between both sides of the RF is manifested in formations that are exposed on the surface. In the western wall of the RF the Cretaceous rocks crop out in the fold cores, while in the eastern wall the rocks of the Paleocene/Eocene 
age (the Łabowa Formation) are the oldest ones and the youngest deposits of the Magura Fm distinctly dominate at the surface (Figure 3). Folds observed in the eastern side of the RF are usually overturned and north-verging (Figure 9).
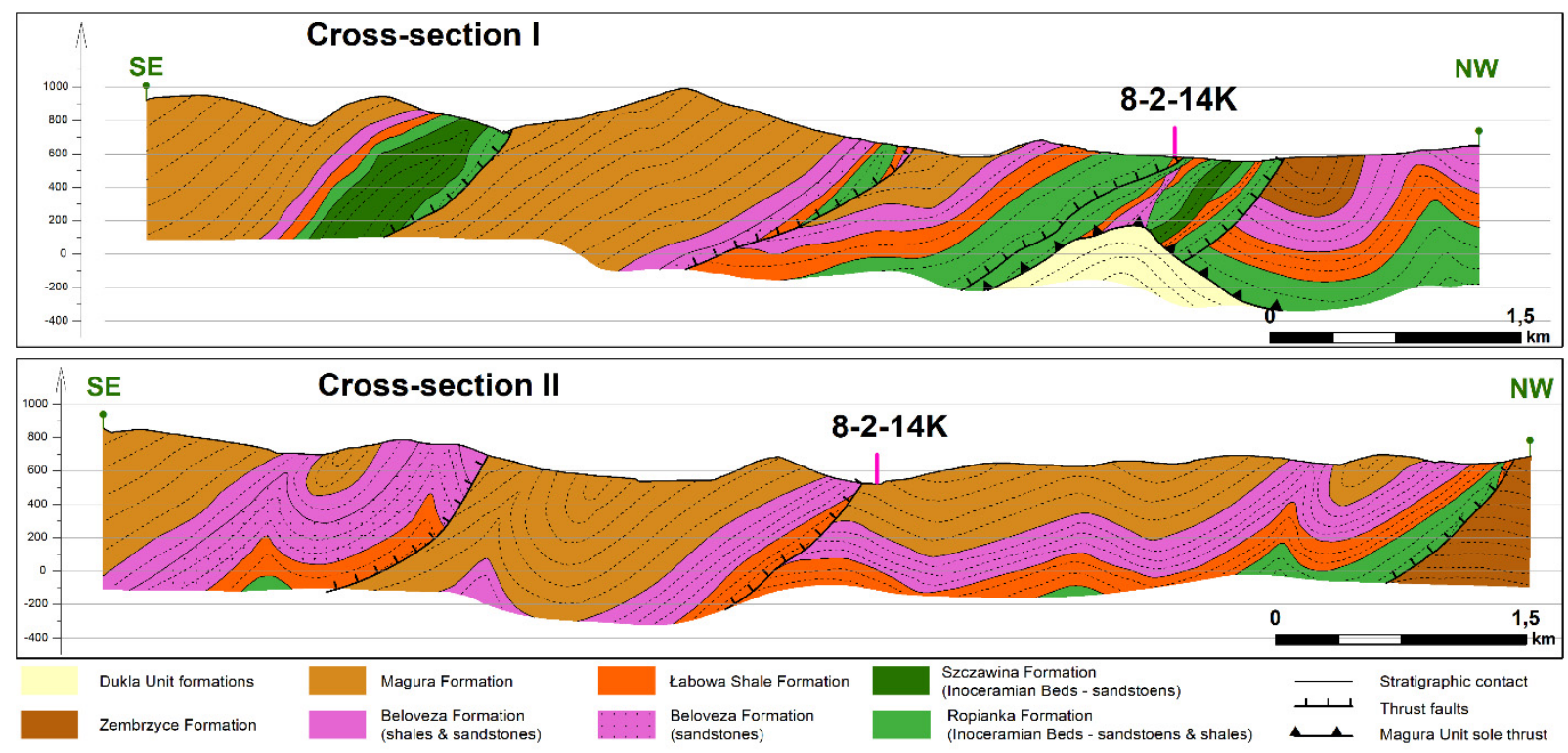

Figure 9. Cross-sections showing a different structural style of the Rača Subunit on the western (Cross-section I) and eastern (Cross-section II) sides of the RF based on surface data. Internal deformations of particular thrust sheets are more complex in the case of Cross-section II, where even the youngest and most competent complex of the Rača Subunit is distinctively folded.

The Rycerka Fault was mapped both in the field and on the shaded relief map (hillshade) derived from the LiDAR Digital Elevation Model (DEM). The RF is one of the most distinctive morphotectonic features recognizable on the hillshade. It manifests as a rectilinear topolineament of considerable length. In the south, it strikes almost in the N-S direction for a distance of about $2.5 \mathrm{~km}$, then it bends to the NE and after $1 \mathrm{~km}$ turns to the NNW (Figures 3 and 7). The Rycerka Stream formes its valley along the fault damage zone of the RF. The bottom of the valley is rather flat, although with several terraces, it has abrupt edges with the base slopes and its width ranges from 100 to $200 \mathrm{~m}$.

The hillshade map reveals also numerous morpho-tectonic lineaments arranged in a horse tail- and splay geometry (Figures 10 and 11). The drainage pattern of the left-hand tributaries at the southern termination of the RF and its NE bending segment are developed along well-visible lineaments interpreted as a second generation of faults displaing the horsetail geometry (Figure 10). A well-developed triangular faceted scarps indicates the presence of another set of fault system superimposed of the above described one (Figure 10b). 

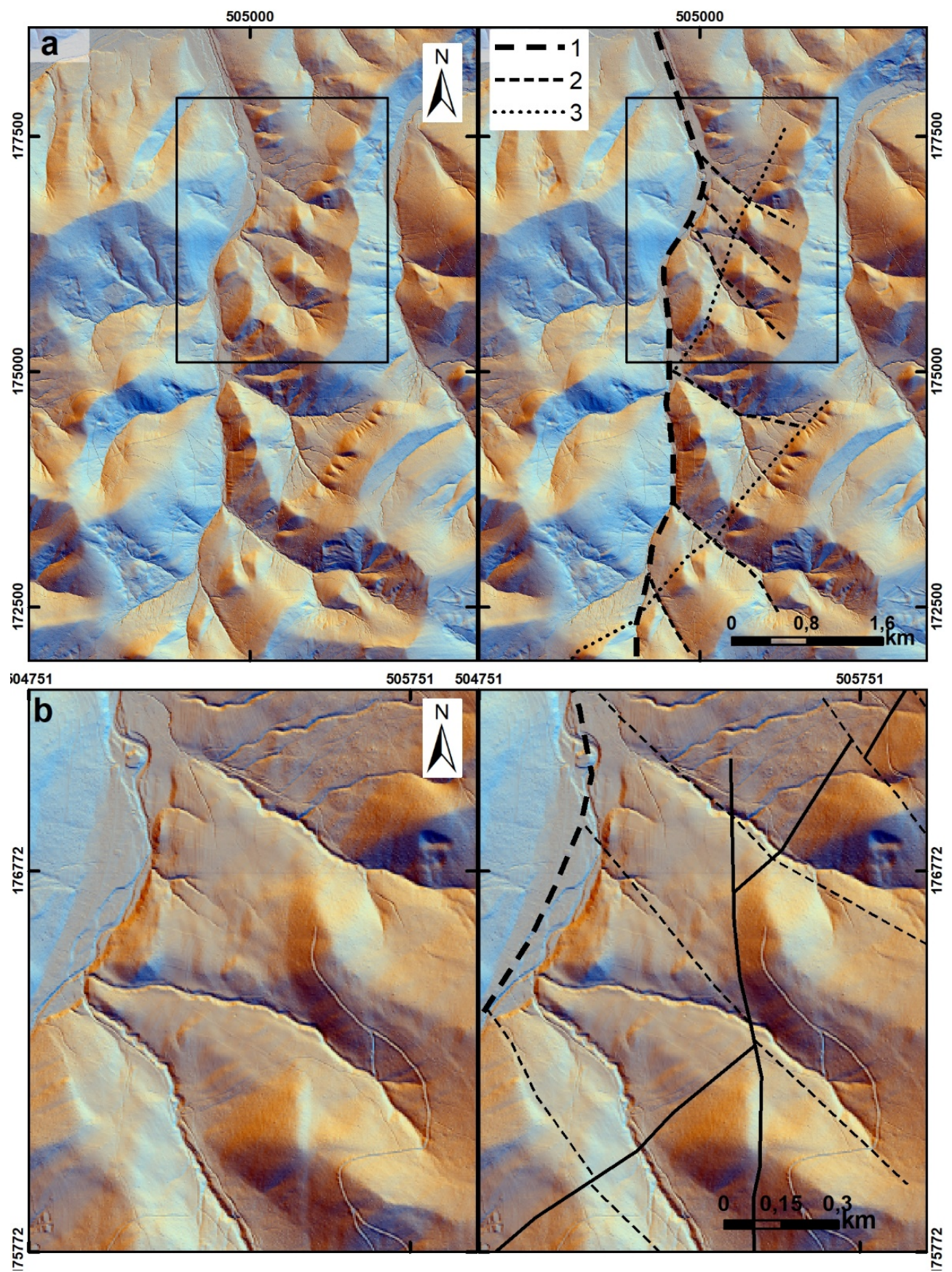

Figure 10. (a) Trace of the Rycerka Fault (thick dashed line-1) with subsidiary faults (thin dashed lines-2) visible on the LiDAR-based DEM. Dotted lines (3) mark the trace of younger generation normal faults, (b) LiDAR-DEM showing morpho-structural lineaments interpreted as faults system on the eastern flank of the Rycerka Fault (thick dashed line). Triangular facet scarps that represent eroded fault planes are marked with pale yellow arrows, solid lines mark the strike of normal faults. Facet scarps can be noticed along the eastern side of the RF, indicating normal faulting also along this fault. 


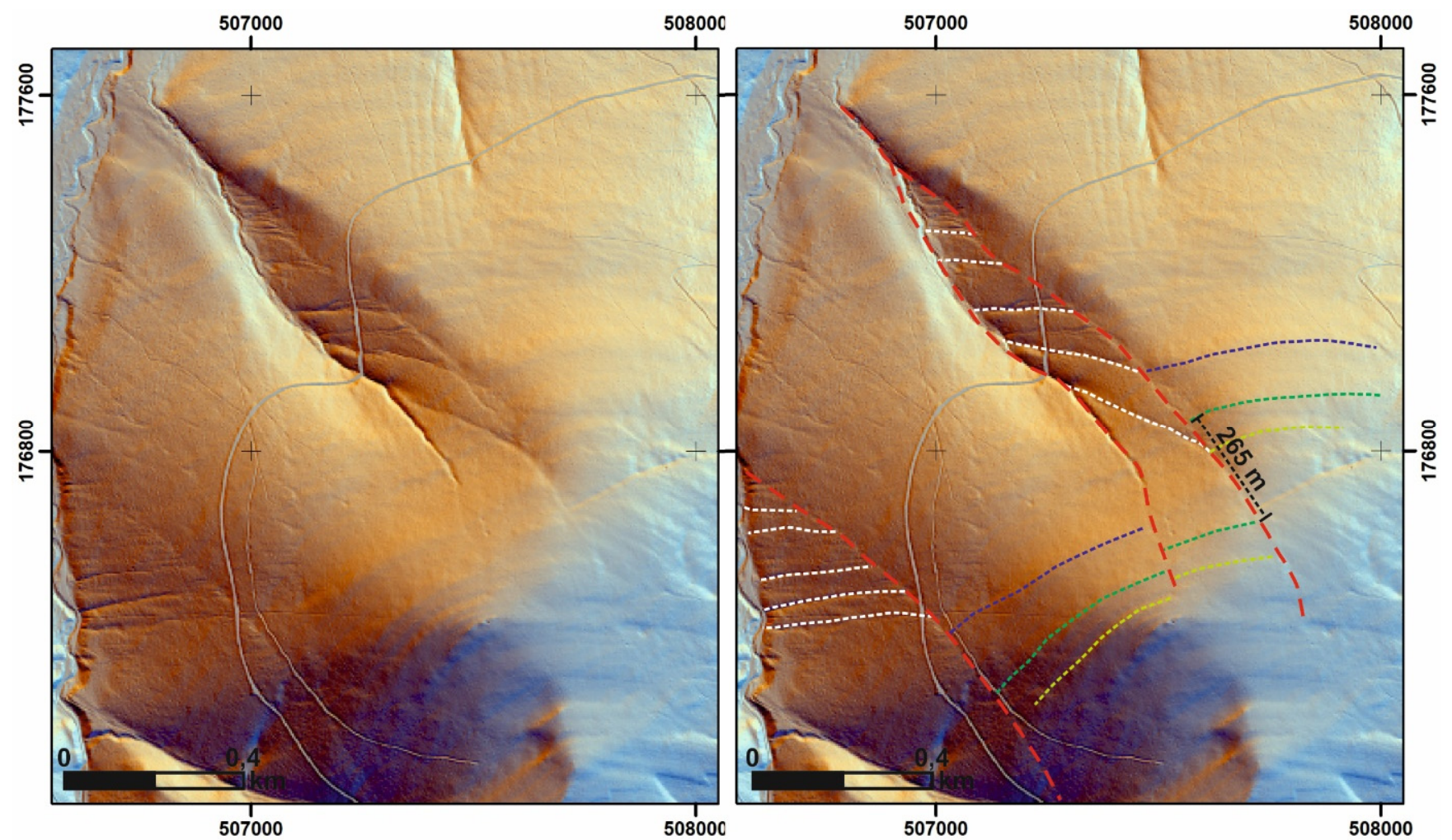

Figure 11. First-order sheared morpho-structural lineaments interpreted as first-order joints (red dashed lines) with asymmetrically developed second-order splay joints (white dashed lines). Yellow, green and dark blue dotted lines show the most distinctive scarp developed on thick sandstone layers more resistant to weathering, which are displaced along the main sheared joint showing a sinistral sense of slip.

Although no hands-on observation of the Rycerka Fault's surface is possible, indirect indicators of fault-related deformations can be identified along riverbed and banks of the Rycerka Stream. The fault trace is marked with outcrops of deformed and disrupted rocks, but also units of which original bedding is completely or partly preserved (Figure 12). In the latter case, the fault manifests by the occurrence of two different rock complexes at the opposite banks of the Rycerka Stream (Figure 12a). Even though their direct contact is covered by the river-bed debris it can be assumed that they do not form a continuous rock body because such a short distance and sedimentological character exclude facies changes. Therefore, the occurrence of such two complexes in close vicinity must be a result of movement along a discontinuous surface.

Because on a long distance the RF cuts the Magura Formation, outcrops of thickbedded sandstones densely cut by faults or even completely brecciated are the most frequently observed feature along the fault trace (Figure 12b). In most fractured zones alteration of sandstone colours (bleaching) can be observed indicating that they were privileged circulation pathways for enriched waters from deeper parts of the Carpathian belt. On the other hand, within shale intervals pervasiv scaly fabric is developed, i.e., shales are deformed by anastomosing cleavage planes, which split the matrix in a millimetre to centimetre lens-shaped scales inferring their tectonic origin (Figure 12c) [84]. Some fractured surfaces of sandstones sometimes disclose slickenlines. In most instances, they indicate a normal dip-slip motion, although in one case also two different generations of slickenslines along the same fault plane were documented indicating strike-slip and dip-slip motion (Figure 12d). 

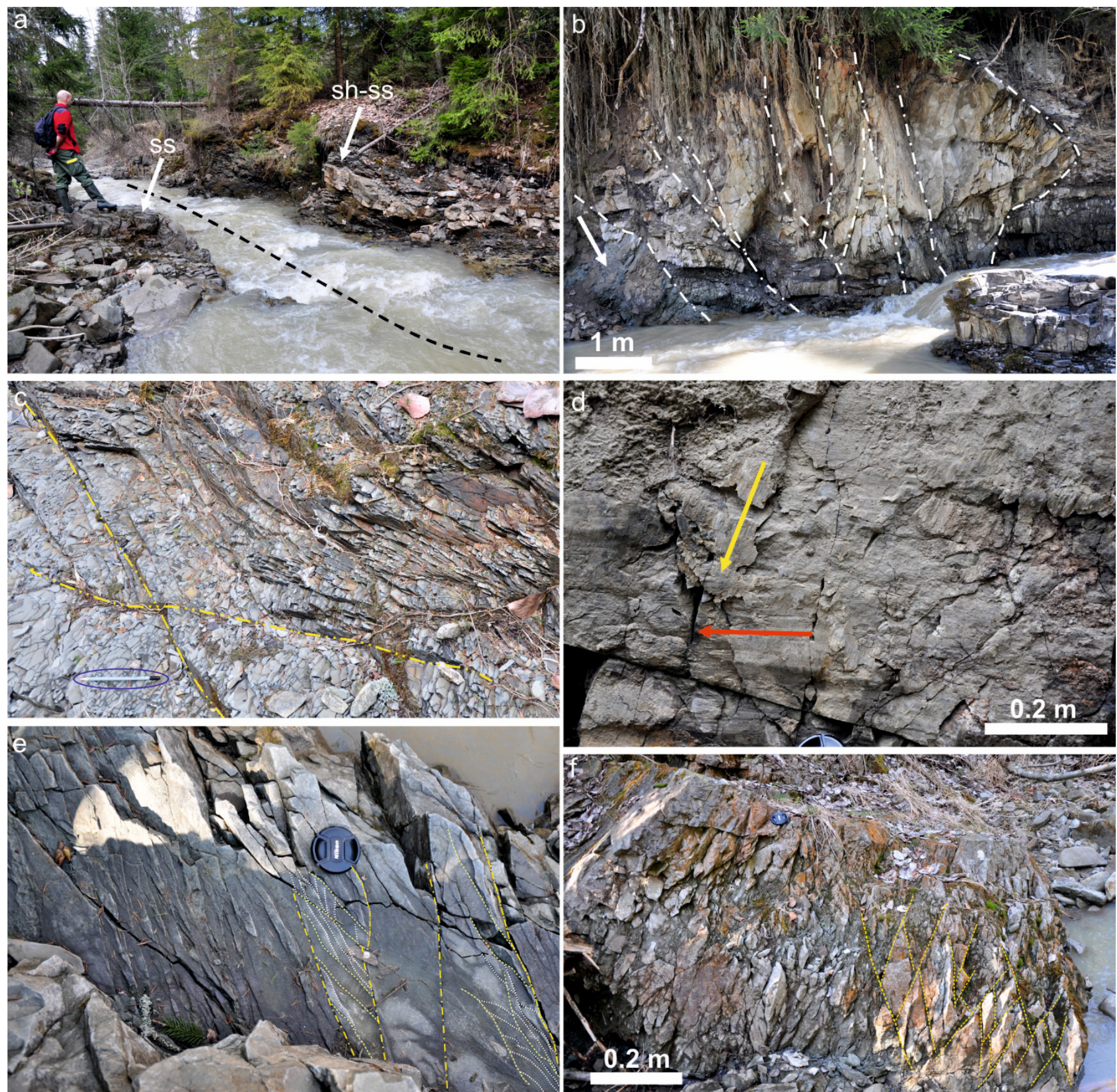

Figure 12. Outcrop fault indicators: (a) discontinuity in lithology on the opposite river banks (black dashed line)—shalesandstone packet of layers on the right (sh-ss) and thick sandstone layer on the left (ss), (b) thick-bedded sandstones of the Magura Fm. densely fractured sandstones (white dashed line) with clay mineral veins and bleaching colours resulted due to the cement alteration during fluid migration indicated by an arrow, (c) scaly fabric in shales, pervasive in fault zone, almost no visible sedimentary bedding of shales due to many intersecting, sharply defined shear surfaces (yellow lines), (d) two generations of the slickensides, coated by mineral fibres, indicating strike-slip (red arrow) and dip-slip (yellow arrow) sense of movement, (e) upper surface of sandstone layer showing several generations of splay joints-initial sheared joints marked with thicker dashed lines, first generation of splay joints with dotted yellow lines, and secondary splay joints with white dotted lines, (f) fracture network (yellow lines) in the competent rock (sandstone) causing its fragmentation into rhomboidal pieces. 


\subsection{Seismic Data Interpretation}

For the need of this study, two seismic profiles were interpreted (Figures 3, 13 and 14). The poor quality of the seismic data allowed for interpreting only the first-order structures. Due to the uncertainty of the seismic data and lack of deep wells with checkshot and well logs available, the seismic-to-well tie process was impossible to perform, and therefore the seismic horizons were tentatively tied to the lithostratigraphic formations based on the available geological map.
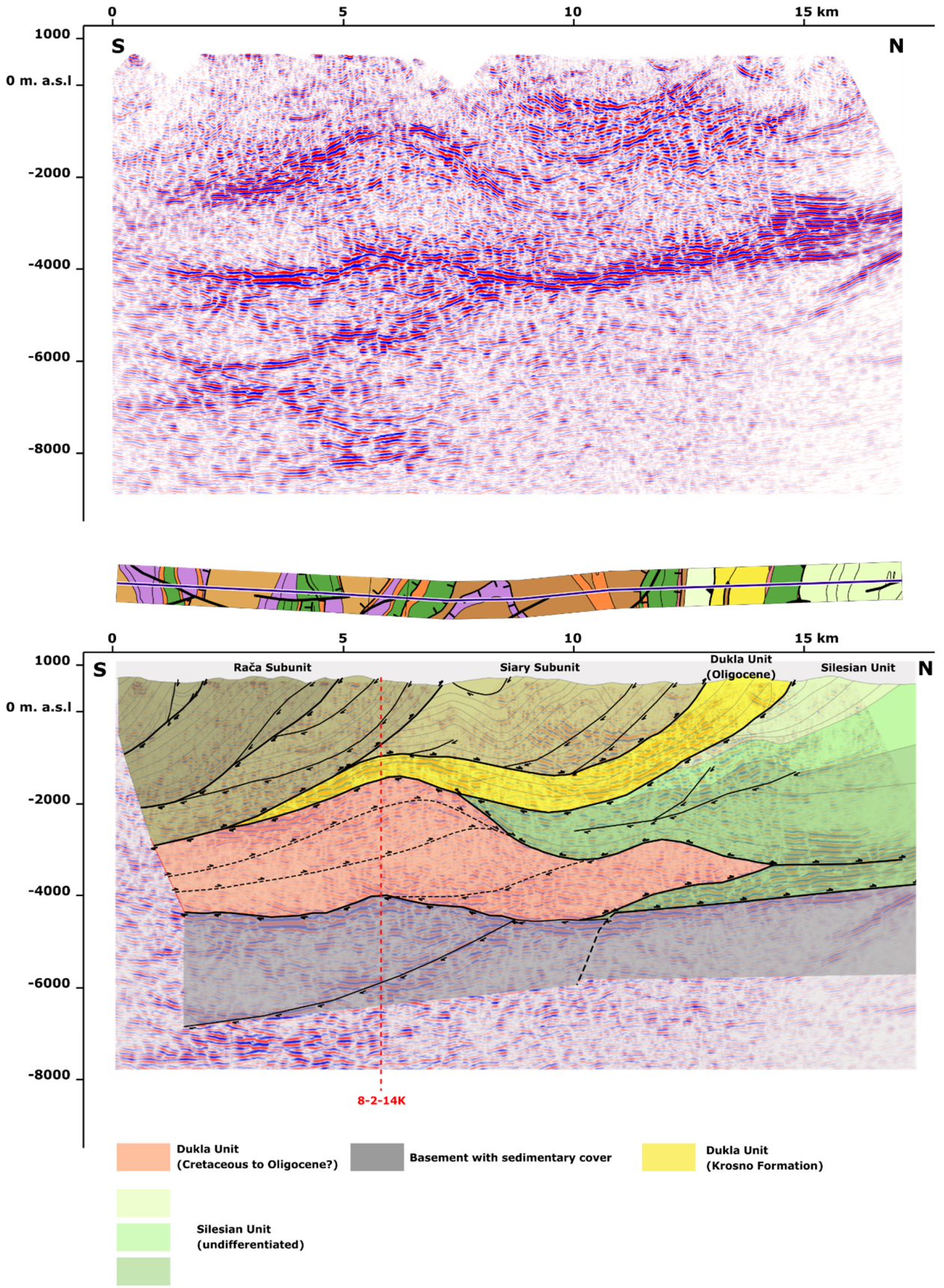

Figure 13. Depth migrated seismic profile 12-2-14K (upper panel) and its interpretation (lower panel). The black vertical line indicates an intersection with the 8-2-14K seismic profile. Black lines - thrust faults, dashed black lines - inferred normal faults. Red dashed line-intersection with seismic profile $8-2-14 \mathrm{~K}$. Above the interpreted seismic profile a fragment of the geological map is presented. Abbreviation: m. a.s.l一meters above sea level. 

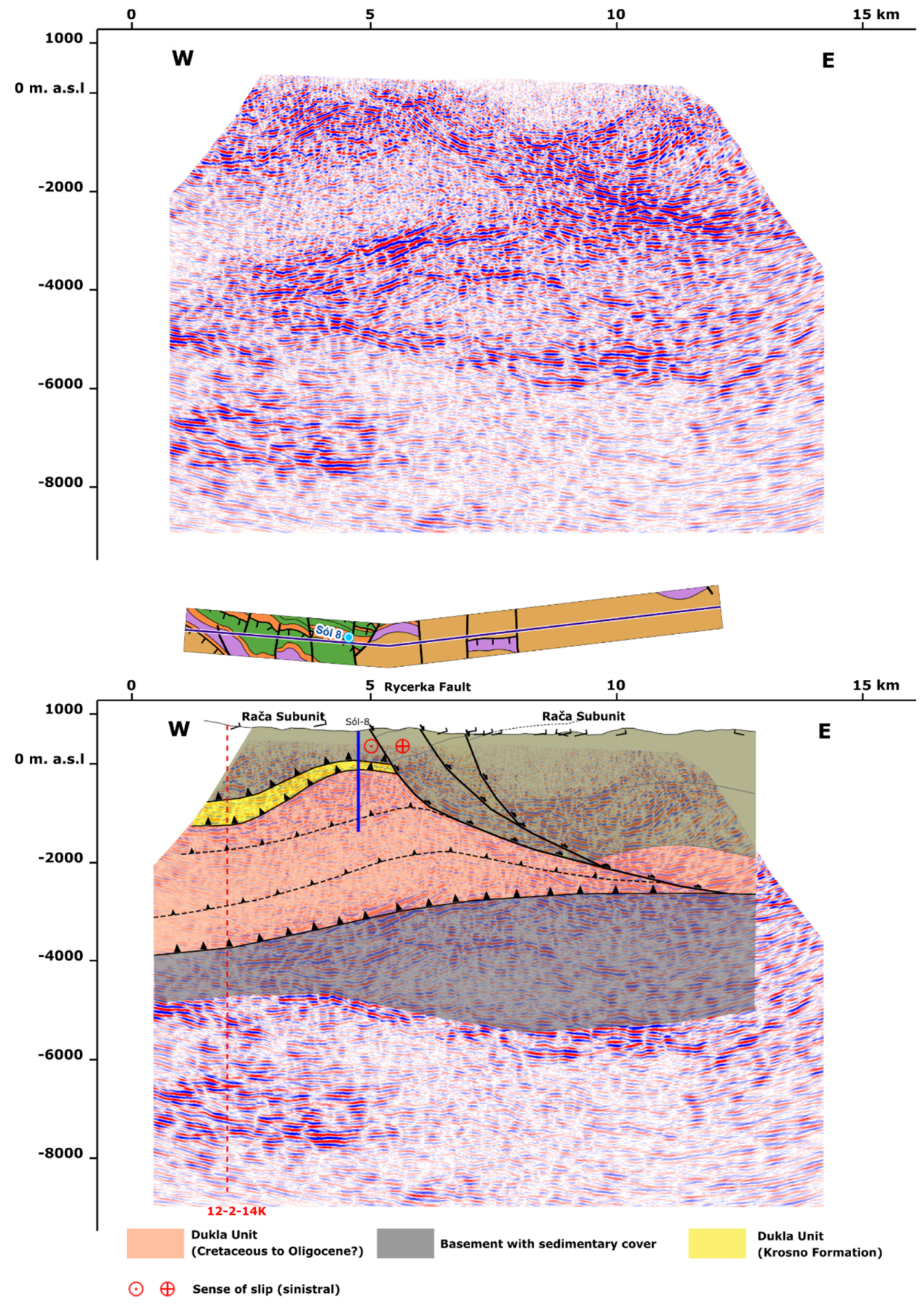

Figure 14. Depth Migrated seismic profile 8-2-14K (upper panel) and its interpretation (lower panel). The black vertical line indicates an intersection with the 12-2-14K seismic profile. Black lines-normal and thrust faults, dashed black lines-anticipated second-order thrust within the anticlinal stack. Red line-intersection with the 12-2-14K seismic profile. Above the interpreted seismic profile a fragment of the geological map is presented. Colour coding as in Figure 13. Abbreviation: m. a.s.l-meters above sea level.

On the 12-2-14K seismic line running perpendicular to main geological structures, three main tectonic units could be identified from top to bottom (Figure 13). The shallowest part of the profile is occupied by the Magura Unit composed of two second-order subunits, i.e the Rača Subunit and the Siary Subunit. In front of the Magura Unit, a narrow zone of the Dukla Unit composed mainly of the Krosno Beds. Below the Magura Unit, an anticlinal duplex stack was interpreted. As confirmed by the results of the Sól-8 borehole, 
the anticlinal stack is built of the sedimentary sequence of the Dukla Unit. Below the Carpathian units, a zone of strong reflectors is visible. Due to the lack of deep wells, based on the results of Golonka et al. [85] and recent works of the authors [71,86], these reflections have been identified as the top of the sedimentary cover of the North European Platform, most likely represented by Devonian and Carboniferous sediments.

The interpretation of the 8-2-14K seismic profile integrated with the geological map and dip measurements led to the identification of a large scale detachment fault, i.e., the Rycerka Fault, accompanied by the second-order synthetic faults (Figure 14). Despite the low quality of the seismic data, the main fault surface is visible. The fault surface dips to the east with the detachment located at the base of the Carpathian Units. Due to the lack of reliable and continuous seismic reflectors, the hanging-wall structure was interpreted mainly based on the geological map and dip measurements. Above the fault's surface, relatively undeformed sheets of the Dukla and Magura Units are interpreted. Because of limitations in seismic data quality, the thickness of the Dukla Unit was estimated based on interpretation of the $12-2-14 \mathrm{~K}$ profile, where it lies undeformed in the front of the anticlinal stack (Figure 13). In the footwall, below the fault surface, the tectonically repeated stratigraphy of the Dukla Unit was interpreted. Identically to the 12-2-14K seismic profile, no seismic reflectors were observed within the duplex stack. The base of the Carpathian units is marked by strong reflections representing sedimentary cover of the North European Platform (Figures 13 and 14).

\section{Discussion-Deciphering the Faulting Mechanism}

The analysis of geological map and field observations reveal that the main difference between the western and eastern sides of the RF boils down to the structural geometry of the Rača Unit. To the west of the RF, the Rača Unit consists of numerous stacked thrust related folds that are relatively narrow and for which sole thrust is within the Cretaceous deposits. The structure of the western area is characterized by significantly wider thrust sheets in which mostly younger stratigraphical levels are preserved and with detachment running within Paleocene and Eocene rock complexes. The internal structural complexity of these thrust sheets is higher due to the occurrence of hundreds-meters scale folds within the Magura Formation. Such differences suggest that these two areas evolved independently. It implicates that, during the folding and thrusting phase, the RF was already an important structural feature controlling development of the OCTFB in this area. The sigmoidal bending of the fold axis (Figure 7) unequivocally points to the sinistral movement along the RF.

The analysis of the DEM allows to identified a few second-order sets of faults and fractures associated with the RF. The map-view arrangement of these features, i.e., horsetail and splay fractures, supports the assumption of a strike-slip character of the RF. In addition, a linear trough along-fault is a typical geomorphologic feature indicative of strike-slip faulting [87]. Such linear valleys commonly form along the fault damage zone, because structural blocks slide along such zones causing fracturing (brecciation) of rocks which are more easily eroded. On the other hand, the triangular facets, which, to our interpretation, are a topographic expression of normal faults (e.g., [87-89]) are assumed to be formed during the last, post-compressional stage of the Carpathian orogen development (e.g., $[18,19])$. Similar morphological features are noted by Jankowski and co-authors [90] in the central part of the Polish Carpathians.

Observed outcrop-scale structural features characteristic for transtension systems include sheared joints, smaller-scale faults with millimetres to centimetres of slip [91-94]. Such structures were identified on the sandstone layers' surfaces (Figure 12e). They are developed as a result of shearing of pre-existing joints that produces the first order splay fracturing in regions of high tensile stress (e.g., $[95,96])$. Further accumulation of strain results in formation of second-order splay joints along the first order ones. These joints are referred to as horsetail fractures [97] or splay fractures [98]. All these structures may show slightly different angular relationships to the master fault at small and large scale 
but develop in response to similar stress distribution and mechanics around the fault [99]. Shearing of pre-existing joints and formation of secondary ones generates a distinctive fragmentation style of rocks that are divided into roughly rhomboidal blocks (Figure 12f).

Our interpretation of seismic data shows that the extent of imbrication within the Dukla Unit is limited to the footwall of the RF suggesting that the imbrication was a factor controlling the formation of the RF.

An explanation of the occurrence of extension in the hangingwalls of thrusts leading to normal faulting was given by Butler $[100,101]$. To date, such structures have not been widely studied and have been mentioned only in a few works (e.g., [102-106]). According to Butler $[100,101]$, when considering stacking in the lower layer of a simple two-layer horizontal three-dimensional model, it can be noticed that the upper layer will be uplifted above the duplex formed in the lower layer (Figure 15). Analyzing a cross-section parallel to the thrust line before and after thrusting, it can be noticed that as a result of the tectonic imbrication of the lower layer, a relatively narrow, dome-like structure is formed and the upper layer undergoes extension, which is then accumulated along so-called lateral culmination walls (Figure 15b). In consequence, lateral culmination walls represent zones favourable for normal faulting. Based on the terminology proposed by Butler $[100,101]$, the fault resulting from such a process should be named as a hanging-wall drop fault, as it is related to differential uplift above the duplex or anticlinal stack, and it does not accommodate different displacement along the thrust sheet.
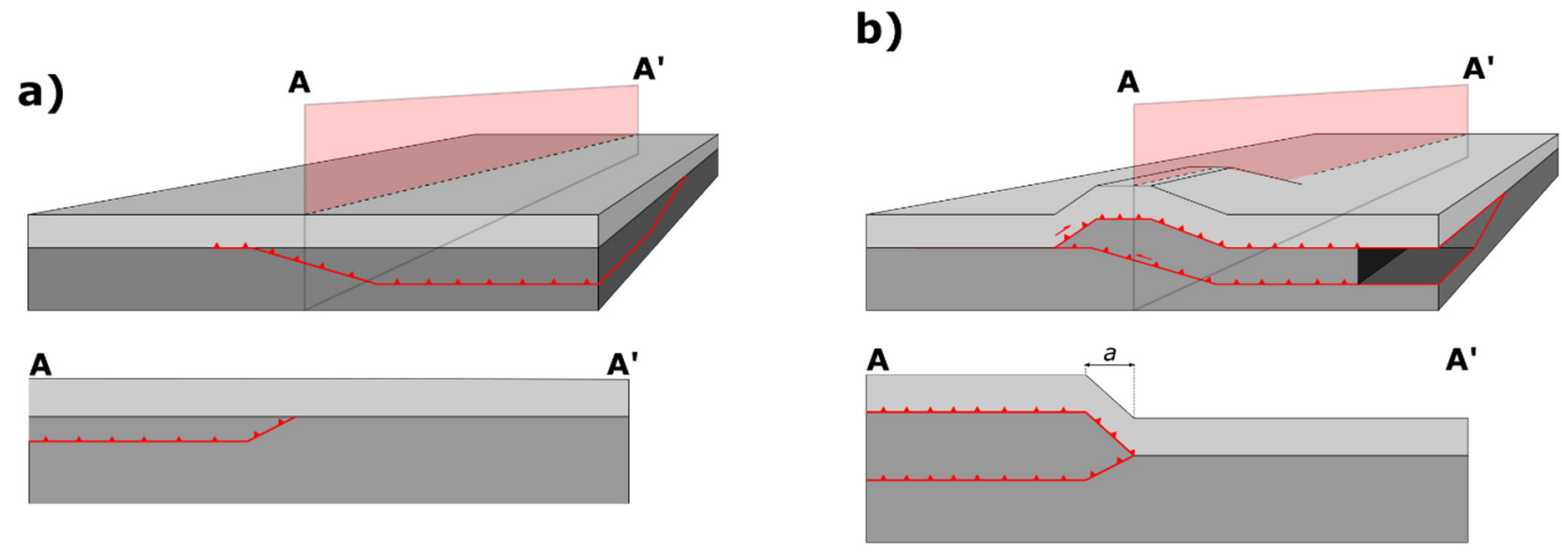

Figure 15. Schematic cartoon (not to scale) showing the mechanism responsible for extension in the hanging-wall lateral culmination wall. (a) A simple two-layer model with a future thrust marked by the red line, (b) Duplex formation causing doming of the upper lay, based on $[100,101]$.

According to this scheme, hanging-wall drop faults should be restricted only to the upper layer. Given the spatial relationship between the anticlinal stack formed within the Dukla Unit and the RF, it is highly probable that the faulting was initiated by the mechanism described above. However, the presented interpretation (Figures 13 and 14) indicates that the detachment surface of the RF is located at the base of the Carpathian units-such a geometry would be impossible to achieve if the faulting mechanism described above would be considered as an exclusive. It is anticipated that an approximately $\mathrm{W}$-E orientated extension was the mechanism leading to the formation of a detachment fault in a zone previously weakened by the hanging-wall drop fault (Figure 16). It is proposed that the WE directed extension was induced by the radial extension. The hanging-wall drop faulting mechanism, as well as radial-extension related normal faulting do not explain the sinistral displacement visible in the map (Figure $4 \mathrm{~b}$ ). We interpret the horizontal offset as a result of a tear faulting $[93,107]$. Considering the described structural differences in the western and eastern sides of the RF, the primary transverse tear faulting is implied. 

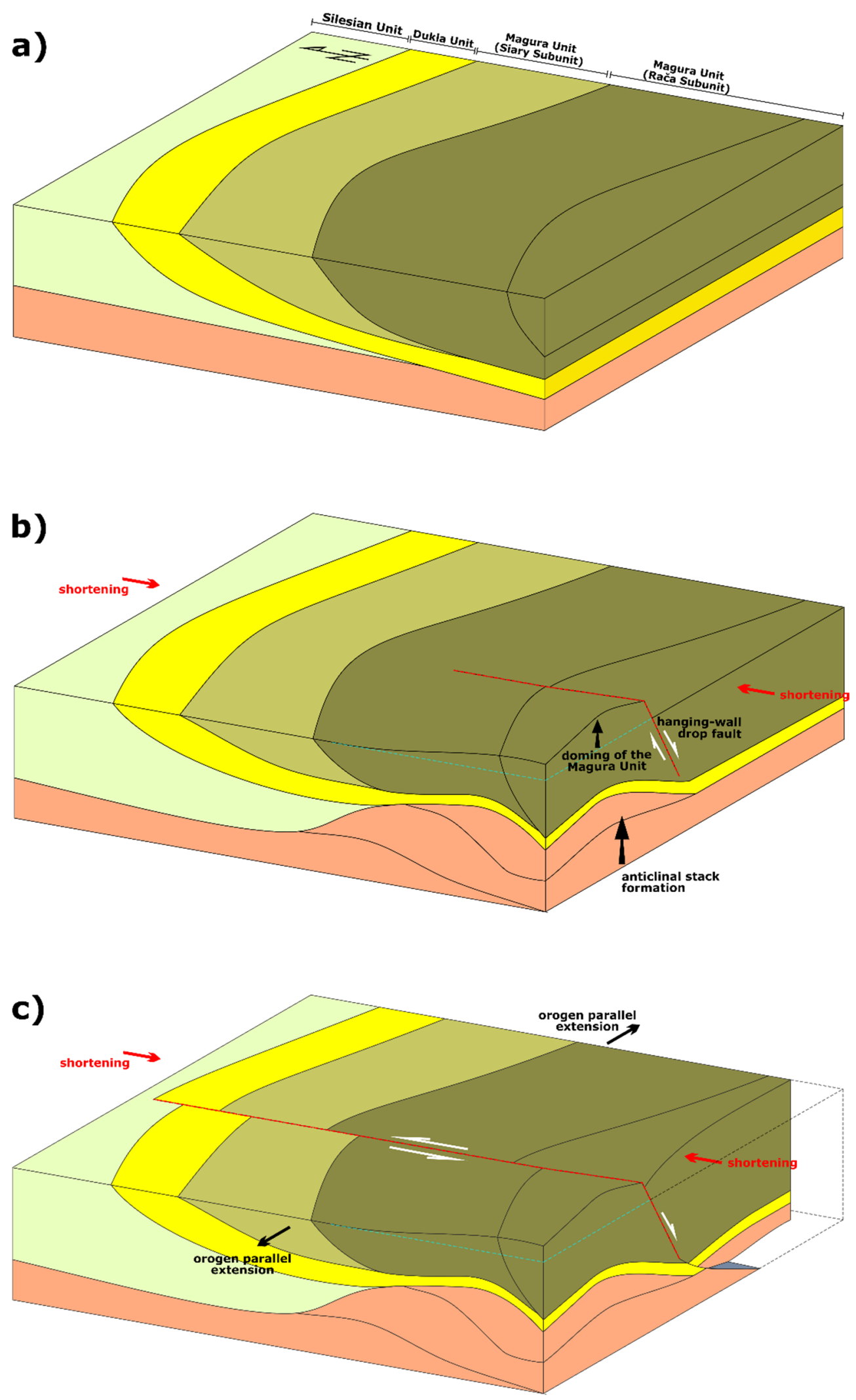

Figure 16. Cartoon showing the anticipated mechanism of the Rycerka Fault formation marked with a black-red dashed line (not in scale). (a) Pre-faulting situation. (b) Anticlinal stacking within the Dukla Unit and hanging-wall drop fault formation. (c) re-shaping of the Rycerka Fault in sinistral, transtensional settings related to orogen parallel extension. Colour coding as in previous figures. White arrows indicate movement along the Rycerka Fault. See the text for more explanation. 
Despite limited slickenlines measurments, the results of stress inversion is with agreement with the break-out analysis in the Sól-8 borehole [77,78] and together point to the present-day normal faulting regime with almost vertical S1 and $\mathrm{Sh}_{\max }$ (the equivalent of S2) directed to NNE (c.a. $30^{\circ}$ ). Such an arrangement of the stress field does not explain the sinistral displacement along the RF, suggesting that the RF was formed before the formation of the current stress field.

Although, despite the limitations of available datasets, related mainly to limited structural measurments and low quality of seismic data, the mechanism of the RF formation is believed to be adequately explained, the timing of subsequent phases of development is poorly constrained. It can be tentatively determined based on the superposition principle, i.e., on the fact that the basal thrust of the Magura Unit and the youngest formations of the Rača and Siary Subunits (i.e., Magura and Zembrzyce Formations, respectively) are deformed as a result of duplex stacking and normal faulting (Figure 16). On the other hand, it should be ruled out that the sinistral strike-slip faulting occurred under the recent (late Miocene (?)-present-day) day stress regime since the breakout analysis from the Sól- 8 borehole and results of stress inversion show almost vertical S1 and NNE orientated $\mathrm{Sh}_{\max }$ (Figures $4 \mathrm{a}, \mathrm{b}$ and 5) excluding sinistral displacement. Considering the above, the RF should be regarded as of syn-thrusting origin (not younger than Early/Middle Miocene?). This assumption can be supported by the results of Beidinger and Decker [51], who distinguished an NNW directed shortening phase lasting until the early Middle Miocene, which may induce the sinistral strike-slip movement along almost N-S striking RF. This concept corresponds also with the general observations of Unrug [10] and Morley [12], who links the formation of the regional, strike-slip faults with advancing of the OC accretionary prism and the arcuate shape of the orogen.

We suggest that the RF was formed as a combination of at least three different faulting mechanisms, i.e., hanging-wall drop faulting, arc-parallel extension-related normal faulting and tear faulting. Performed investigations suggest that the RF formation was initiated as a hanging-wall drop fault and was reshaped by two other faulting mechanisms, which most probably acted almost simultaneously, or at least within a short time span. While the tear faulting is a well-known process and the hanging-wall drop faulting should be regarded as a local phenomenon, the arc-parallel extension seems to be a satisfactory explanation for dip-slip movement on the RF and should be considered as an important and regional scale process [12].

\section{Summary}

Based on the available data, a large scale detachment fault cross-cutting the whole complex of the Carpathian units has been interpreted. Despite the limitations of the available data related to the seismic data quality and poor exposure of the fault zone, the geometry of the Rycerka Fault was described and an attempt was made to explain the relationships between the fault and the anticlinal stack as well as to decipher the faulting mechanism. We have concluded that the RF originated as a hanging-wall drop fault formed above the anticlinal stack and was later reshaped due to the orogen-parallel extension and tear-faulting. As a result, we suggest the early Miocene as the main stage of the Rycerka Fault formation.

By our results, we emphasise the importance of the orogen-parallel extension in shaping the structure of the Outer Carpathian Fold and Thrust Belt. The orogen-parallel extension in the Polish Outer Carpathians and its effect on the orogen evolution, although mentioned in several papers (see Introduction), so far is not sufficiently elaborated. Nonetheless, such a process should be anticipated based on theoretical assumptions, modelling and well-documented observations in the Carpathians and other thrust and fold belts [6-9,29-31,33,34,40,108]. We suggest that numerous thrust-perpendicular or oblique normal faults visible in recent geological maps [15] might have originated, or at least be reshaped, by this process. 
Author Contributions: Conceptualization, J.B. and K.S.; methodology, J.B., K.S. and W.S.; formal analysis, J.B. and K.S.; investigation, J.B. and K.S. and W.S.; writing-original draft preparation, J.B. and K.S.; writing-review and editing, J.B.; visualization, J.B., K.S. and W.S.; project administration, J.B.; funding acquisition, J.B. and K.S. All authors have read and agreed to the published version of the manuscript.

Funding: This research was funded by the National Centre for Research and Development (NCBiR), grant number BG2/ShaleCarp/14 and J.B. and K.S. were funded by research grant number 16.16.140.315 from the AGH University of Science and Technology. J.B. was additionally finanaced by the Dean's Grant number 15.11.140.182.

Data Availability Statement: Not applicable.

Acknowledgments: We would like to thank two Anonymous Reviewers for their insightful comments which helped us to improve the manuscript significantly. Journal's editors are thanked for their editorial work. For structural and seismic data analysis and interpretation, the authors acknowledge the use of the Move Software Suite granted by the Petroleum Experts Ltd.

Conflicts of Interest: The authors declare no conflict of interest.

\section{References}

1. Golonka, J.; Waśkowska, A.; Ślączka, A. The Western Outer Carpathians: Origin and evolution. Z. Dtsch. Ges. Geowiss. 2019, 170, 229-254. [CrossRef]

2. Kováč, M.; Márton, E.; Oszczypko, N.; Vojtko, R.; Hók, J.; Králiková, S.; Plašienka, D.; Klučiar, T.; Hudáčková, N.; OszczypkoClowes, M. Neogene palaeogeography and basin evolution of the Western Carpathians, Northern Pannonian domain and adjoining areas. Glob. Planet. Chang. 2017, 155, 133-154. [CrossRef]

3. Kováč, M.; Plašienka, D.; Soták, J.; Vojtko, R.; Oszczypko, N.; Less, G.; Ćosović, V.; Fügenschuh, B.; Králiková, S. Paleogene palaeogeography and basin evolution of the Western Carpathians, Northern Pannonian domain and adjoining areas. Glob. Planet. Chang. 2016, 140, 9-27. [CrossRef]

4. Gagała, Ł.; Vergés, J.; Saura, E.; Malata, T.; Ringenbach, J.C.; Werner, P.; Krzywiec, P. Architecture and orogenic evolution of the northeastern Outer Carpathians from cross-section balancing and forward modeling. Tectonophysics 2012, 532, 223-241. [CrossRef]

5. Schmid, S.M.; Fügenschuh, B.; Kounov, A.; Maţenco, L.; Nievergelt, P.; Oberhänsli, R.; Pleuger, J.; Schefer, S.; Schuster, R.; Tomljenović, B. Tectonic units of the Alpine collision zone between Eastern Alps and western Turkey. Gondwana Res. 2020, 78, 308-374. [CrossRef]

6. Mancktelow, N.S. Neogene lateral extension during convergence in the Central Alps: Evidence from interrelated faulting and backfolding around the Simplonpass (Switzerland). Tectonophysics 1992, 215, 295-317. [CrossRef]

7. Wawrzyniec, T.F.; Selverstone, J.; Axen, G.J. Styles of footwall uplift along the Simplon and Brenner normal fault systems, central and Eastern Alps. Tectonics 2001, 20, 748-770. [CrossRef]

8. Campani, M.; Herman, F.; Mancktelow, N. Two-and three-dimensional thermal modeling of a low-angle detachment: Exhumation history of the Simplon Fault Zone, central Alps. J. Geophys. Res. Solid Earth 2010, 1-25. [CrossRef]

9. Rosenberg, C.L.; Garcia, S. Estimating displacement along the Brenner Fault and orogen-parallel extension in the Eastern Alps. Int. J. Earth Sci. 2011, 100, 1129-1145. [CrossRef]

10. Unrug, R. Tectonic rotation of flysch nappes in the Polish Outer Carpathians. Ann. Soc. Geol. Pol. 1980, 50, 27-39.

11. Aleksandrowski, P. A structure of the Mount Babia Góra region (Magura nappe, Western Outer Carpathians): An inference of West and East Carpathians fold trends. Ann. Soc. Geol. Pol. 1985, 55, 375-422. (In Polish)

12. Morley, C.K. Models for relative motion of crustal blocks within the Carpathian region, based on restorations of the outer Carpathian thrust sheets. Tectonics 1996, 15, 885-904. [CrossRef]

13. Rubinkiewicz, J. Development of fault pattern in the Silesian nappe: Eastern Outer Carpathians, Poland. Geol. Q. 2000, 44, 391-404.

14. Jankowski, L.; Margielewski, W. Strukturalne uwarunkowania rozwoju rzeźby Karpat zewnętrznych-Nowe spojrzenie. Przeglad Geologiczny 2014, 62, 29-35.

15. Jankowski, L.; Kopciowski, R.; Ryłko, W.; Małecka, J.; Ogrodowczyk, W.; Szewczyk, A. Geological Map of the Outer Carpathians: Borderlands of Poland, Ukraine and Slovakia: 1: 200000; Polish Geological Institute: Warsaw, Poland, 2004.

16. Jankowski, L. Nowe Spojrzenie na Budowę Geologiczna Karpat-Ujęcie Dyskusyjne; Prace Naukowe Instytutu Nafty i Gazu: Kraków, Poland, 2015; pp. 1-154.

17. Mazzoli, S.; Jankowski, L.; Szaniawski, R.; Zattin, M. Low-T thermochronometric evidence for post-thrusting (<11 Ma) exhumation in the Western Outer Carpathians, Poland. Comptes Rendus Geosci. 2010, 342, 162-169. [CrossRef]

18. Zattin, M.; Andreucci, B.; Jankowski, L.; Mazzoli, S.; Szaniawski, R. Neogene exhumation in the Outer Western Carpathians. Terra Nova 2011, 23, 283-291. [CrossRef] 
19. Andreucci, B.; Castelluccio, A.; Jankowski, L.; Mazzoli, S.; Szaniawski, R.; Zattin, M. Burial and exhumation history of the Polish Outer Carpathians: Discriminating the role of thrusting and post-thrusting extension. Tectonophysics 2013, 608, 866-883. [CrossRef]

20. Castelluccio, A.; Mazzoli, S.; Andreucci, B.; Jankowski, L.; Szaniawski, R.; Zattin, M. Building and exhumation of the Western Carpathians: New constraints from sequentially restored, balanced cross sections integrated with low-temperature thermochronometry. Tectonics 2016, 35, 2698-2733. [CrossRef]

21. Zuchiewicz, W. Morphological development of the Beskid Niski Mts and Quaternary palaeogeography of the Polish Flysch Carpathians. Kwart. Geol. 1989, 33, 541-560.

22. Zuchiewicz, W. Selected aspects of neotectonics of the Polish Carpathians. Folia Quat. 1995, 66, 145-204.

23. Zuchiewicz, W. Przydatność metod morfometrycznych w ocenie tendencji neotektonicznych Karpat polskich. Przegląd Geologiczny $1999,47,851-854$.

24. Zuchiewicz, W.; Tokarski, A.K.; Jarosiński, M.; Márton, E. Late Miocene to present day structural development of the Polish segment of the Outer Carpathians. Stephan Mueller Spec. Publ. Ser. 2001, 3, 185-202. [CrossRef]

25. Carey, S. The orocline concept in geotectonics-Part I. Pap. Proc. R. Soc. Tasman. 1955, 89, 255-288.

26. Ries, A.C.; Shackleton, R.M. Patterns of Strain Variation in Arcuate Fold Belts. Philos. Trans. R. Soc. A Math. Phys. Eng. Sci. 1976, 283, 281-288. [CrossRef]

27. Eldredge, S.; Bachtadse, V.; Van der Voo, R. Paleomagnetism and the orocline hypothesis. Tectonophysics 1985, 119, 153-179. [CrossRef]

28. Marshak, S. Kinematics of orocline and arc formation in thin-skinned orogens. Tectonics 1988, 7, 73-86. [CrossRef]

29. Merle, O. Strain models within spreading nappes. Tectonophysics 1989, 165, 57-71. [CrossRef]

30. Marshak, S.; Wilkerson, M.S.; Hsui, A.T. Generation of curved fold-thrust belts: Insight from simple physical and analytical models. In Thrust Tectonics; Springer: New York, NY, USA, 1992; pp. 83-92. [CrossRef]

31. Ferrill, D.A.; Groshong, R.H. Kinematic model for the curvature of the northern Subalpine Chain, France. J. Struct. Geol. 1993, 15, 523-541. [CrossRef]

32. Ratschbacher, L.; Linzer, H.G.; Moser, F.; Strusievicz, R.O.; Bedelean, H.; Har, N.; Mogoş, P.A. Cretaceous to Miocene thrusting and wrenching along the central South Carpathians due to a corner effect during collision and orocline formation. Tectonics $\mathbf{1 9 9 3}$ 12, 855-873. [CrossRef]

33. Coleman, M.E. Orogen-parallel and orogen-perpendicular extension in the central Nepalese Himalayas. Bull. Geol. Soc. Am. 1996, 108, 1594-1607. [CrossRef]

34. Hindle, D.; Burkhard, M. Strain, displacement and rotation associated with the formation of curvature in fold belts; the example of the Jura arc. J. Struct. Geol. 1999, 21, 1089-1101. [CrossRef]

35. Hindle, D.; Besson, O.; Burkhard, M. A model of displacement and strain for arc-shaped mountain belts applied to the Jura arc. J. Struct. Geol. 2000, 22, 1285-1296. [CrossRef]

36. Johnston, S.T.; Mazzoli, S. The Calabrian Orocline: Buckling of a previously more linear orogen. Geol. Soc. Lond. Spec. Publ. 2009, 327, 113-125. [CrossRef]

37. Johnston, S.T.; Weil, A.B.; Gutiérrez-Alonso, G. Oroclines: Thick and thin. Bulletin 2013, 125, 643-663. [CrossRef]

38. Márton, E.; Grabowski, J.; Plašienka, D.; Túnyi, I.; Krobicki, M.; Haas, J.; Pethe, M. New paleomagnetic results from the Upper Cretaceous red marls of the Pieniny Klippen Belt, Western Carpathians: Evidence for general CCW rotation and implications for the origin of the structural arc formation. Tectonophysics 2013, 592, 1-13. [CrossRef]

39. Cardello, G.L.; Almqvist, B.S.; Hirt, A.M.; Mancktelow, N.S. Determining the timing of formation of the Rawil Depression in the Helvetic Alps by palaeomagnetic and structural methods. Geol. Soc. Lond. Spec. Publ. 2016, 425, 145-168. [CrossRef]

40. Jiménez-Bonilla, A.; Crespo-Blanc, A.; Balanyá, J.C.; Expósito, I.; Díaz-Azpiroz, M. Analog Models of Fold-and-Thrust Wedges in Progressive Arcs: A Comparison with the Gibraltar Arc External Wedge. Front. Earth Sci. 2020, 8. [CrossRef]

41. Burchfiel, B.C. Eastern European Alpine system and the Carpathian orocline as an example of collision tectonics. Tectonophysics 1980, 63, 31-61. [CrossRef]

42. Burchfiel, B.C.; Royden, L. Carpathian Foreland Fold and Thrust Belt and Its Relation to Pannonian and Other Basins. AAPG Bulletin 1982, 66, 1179-1195. [CrossRef]

43. Kruczyk, J.; Kadzialko-Hofmokl, M.; Lefeld, J.; Pagač, P.; Tunyi, I. Paleomagnetism of Jurassic sediments as evidence for oroclinal bending of the Inner West Carpathians. Tectonophysics 1992, 206, 315-324. [CrossRef]

44. Zweigel, P. Arcuate accretionary wedge formation at convex plate margin corners: Results of sandbox analogue experiments. J. Struct. Geol. 1998, 20, 1597-1609. [CrossRef]

45. Zweigel, P.; Ratschbacher, L.; Frisch, W. Kinematics of an arcuate fold-thrust belt: The southern Eastern Carpathians (Romania). Tectonophysics 1998, 297, 177-207. [CrossRef]

46. Nemčok, M.; Dilov, T.; Wojtaszek, M.; Ludhová, L.; Klecker, R.A.; Sercombe, W.J.; Coward, M.P. Dynamics of the Polish and Eastern Slovakian parts of the Carpathian accretionary wedge: Insights from palaeostress analyses. Geol. Soc. Lond. Spec. Publ. 2007, 272, 271-302. [CrossRef]

47. Shaw, J.; Johnston, S.T. The carpathian-balkan bends: An oroclinal record of ongoing Arabian-Eurasian collision. J. Virtual Explor. 2012, 43, 4. [CrossRef] 
48. Mahel, M. Tectonic Map of the Carpathian-Balkan Mountain System and Adjacent Areas; GÚDŠ: Bratislava, Slovakia, 1973.

49. Rubinkiewicz, J. Fold-thrust-belt geometry and detailed structural evolution of the Silesian nappe-Eastern part of the Polish Outer Carpathians (Bieszczady Mts.). Acta Geol. Pol. 2007, 57, 479-508.

50. Jankowski, L.; Probulski, J. Rozwój tektoniczno-basenowy Karpat zewnętrznych na przykładzie budowy geologicznej złóż Grabownica, Strachocina i Łodyna oraz ich otoczenia. Geologia-Akademia Górniczo-Hutnicza Im. Stanisława Staszica w Krakowie 2011, 37, 555-583.

51. Beidinger, A.; Decker, K. Paleogene and Neogene kinematics of the Alpine-Carpathian fold-thrust belt at the Alpine-Carpathian transition. Tectonophysics 2016, 690, 263-287. [CrossRef]

52. Golonka, J.; Gahagan, L.; Krobicki, M.; Marko, F.; Oszczypko, N.; Ślączka, A. Plate-tectonic Evolution and Paleogeography of the Circum-Carpathian Region. In The Carpathians and Their Foreland: Geology and Hydrocarbon Researches; AAPG Memoir 84. Golonka, J., Picha, F.J., Eds.; American Association of Petroleum Geologists: Tulsa, OK, USA, 2007; pp. 11-46. [CrossRef]

53. Oszczypko, N. Late Jurassic-Miocene evolution of the Outer Carpathian fold-and-thrust belt and its foredeep basin (Western Carpathians, Poland). Geol. Q. 2006, 50, 169-194.

54. Ślączka, A. Geologia Jednostki Dukielskiej; Prace Instytutu Geologicznego, Polish Geological Institute: Warszawa, Poland, 1971.

55. Książiewicz, M. The tectonics of the Carpathians. Geol. Pol. 1977, 4, 476-620.

56. Siemińska, A.; Starzec, K.; Godlewski, P.; Wendorff, M. Sedimentary response to tectonic uplift of the Dukla basin margin recorded at Skrzydlna-The Menilite Beds (Oligocene), Outer Carpathians, S. Poland. Geol. Geophys. Environ. 2018, 44, 231. [CrossRef]

57. Siemińska, A.; Starzec, K.; Waśkowska, A.; Wendorff, M. Sedimentary and diapiric mélanges in the Skrzydlna area (Outer Carpathians of Poland) as indicators of basinal and structural evolution. J. Geol. Soc. 2019, 177, 600-618. [CrossRef]

58. Koszarski, L.; Sikora, W.; Wdowiarz, S. The Flysch Carpathians. Polish Carpathians. Tectonics of the Carpathian-Balkan Regions, Explanations to the Tectonic Map of the Carpathian-Balkan Regions and Their Foreland; Geologický Ústav Dionyza Štura: Bratislava, Slovakia, 1974; pp. 180-197.

59. Ksiazkiewicz, M. Sedimentation in the Carpathian Flysch sea. Geologische Rundschau 1958, 47, 418-425. [CrossRef]

60. Teták, F. The gravity flow dynamics of submarine fan sedimentation in the Magura Basin of the Western Carpathians (Magura Nappe, Slovakia). Geol. Carpathica 2010, 61, 201-209. [CrossRef]

61. Pivko, D. Geology of Pilsko Mountain and surroundings (Flysch belt on northern Orava). Acta Geol. Univ. Comen. 2002, 57, 67-94.

62. Oszczypko, N.; Malata, E.; Bąk, K.; Kędzierski, M.; Oszczypko-Clowes, M. Lithostratigraphy and biostratigraphy of the Upper Albian-Lower/Middle Eocene flysch deposits in the Bystrica and Rača subunits of the Magura Nappe (Beskid Wyspowy and Gorce Ranges; Poland). Ann. Soc. Geol. 2005, 75, 27-69.

63. Sikora, W.; Żytko, K. Geology of the Beskid Wysoki Range south of Żywiec (Western Carpathians). Biuletyn Instytutu Geologicznego 1959, 141, 61-204. (In Polish, English Summary)

64. Malata, E.; Malata, T.; Oszczypko, N. Litho-and biostratigraphy of the Magura Nappe in the eastern part of the Beskid Wyspowy Range (Polish Western Carpathians). Ann. Soc. Geol. Pol. 1996, 66, 269-284.

65. Oszczypko, N. Late Cretaceous through Paleogene evolution of Magura Basin. Geol. Carpathica 1992, 43, $333-338$.

66. Waśkowska, A.; Golonka, J.; Starzec, K.; Cieszkowski, M. Campanian-Paleocene Jaworzynka Formation in its type area (Magura Nappe, Outer Carpathians). Acta Geol. Pol. 2021, 71, 345-370.

67. Książkiewicz, M. Detailed Geological Map of Poland 1: 50,000. Sucha Beskidzka Sheet; Wyd. Geol.: Warsaw, Poland, 1974. (In Polish)

68. Oszczypko, N. Stratigraphy of the Palaeogene deposits of the Bystrica subunit (Magura nappe, Polish Outer Carpathians). Bull. Pol. Acad. Sci. Earth Sci. 1991, 39, 415-431.

69. Golonka, J.; Waśkowska, A. The Beloveža Formation of the Rača Unit in the Beskid Niski Mts. (Magura Nappe, Polish Flysch Carpathians) and adjacent parts of Slovakia and their equivalents in the western part of the Magura Nappe; Remarks on the Beloveža Formation-Hieroglyphic Beds. Geol. Q. 2012, 56, 821-832. [CrossRef]

70. Starzec, K.; Schnabel, W.; Szotek, A.; Pastucha, M. Updating of the Geological Map in Frame of the Project: Seismic Data Aqusition "Sól 2D“; Geokrak Company Archives: Kraków, Poland, 2014.

71. Barmuta, J.; Mikołajczak, M.; Starzec, K. Constraining depth and architecture of the crystalline basement based on potential field analysis-The westernmost polish outer carpathians. J. Geosci. 2019, 64, 161-177. [CrossRef]

72. Burtan, J. Detailed Geological Map of Poland in Scale 1: 50.000, Wisła Sheet; Geological Institute: Warszawa, Poland, 1973.

73. Burtan, J.; Sokołowski, S.; Sikora, W.; Żytko, K. Detailed Geological Map of Poland in Scale 1: 50.000 1: 50000, Milówka Sheet; Geological Institute: Warszawa, Poland, 1956.

74. Ryłko, W.; Żytko, K.; Rączkowski, W. Detailed Geological Map of Poland in Scale 1: 50.000, Czadca-Ujsoty Sheet; Geological Institute: Warszawa, Poland, 1992.

75. Cieszkowski, M.; Ślączka, A.; Wdowiarz, S. New data on structure of the Flysch Carpathians. Przeglad Geologiczny 1985, 33, 313-332.

76. Starzec, K.; Barmuta, J.; Stefaniuk, M. The structure of the silesian and magura units in the westernmost polish outer carpathians. In International Multidisciplinary Scientific GeoConference Surveying Geology and Mining Ecology Management; SGEM. International: Sofia, Bulgaria, 2017; pp. 477-484. [CrossRef] 
77. Jarosiński, M. Contemporary stress field distortion in the Polish part of the Western Outer Carpathians and their basement. Tectonophysics 1998, 297, 91-119. [CrossRef]

78. Jarosinski, M. Ongoing tectonic reactivation of the Outer Carpathians and its impact on the foreland: Results of borehole breakout measurements in Poland. Tectonophysics 2005, 410, 189-216. [CrossRef]

79. Pini, G.A. Tectonosomes and olistostromes in the Argille Scagliose of the Northern Apennines, Italy. Geol. Soc. Am. 1999, 335. [CrossRef]

80. Festa, A.; Dilek, Y.; Pini, G.A.; Codegone, G.; Ogata, K. Mechanisms and processes of stratal disruption and mixing in the development of mélanges and broken formations: Redefining and classifying mélanges. Tectonophysics 2012, 568-569, 7-24. [CrossRef]

81. Festa, A.; Pini, G.A.; Dilek, Y.; Codegone, G.; Vezzani, L.; Ghisetti, F.; Lucente, C.C.; Ogata, K. Peri-Adriatic mélanges and their evolution in the Tethyan realm. Int. Geol. Rev. 2010, 52, 369-403. [CrossRef]

82. Festa, A.; Pini, G.A.; Ogata, K.; Dilek, Y. Diagnostic features and field-criteria in recognition of tectonic, sedimentary and diapiric mélanges in orogenic belts and exhumed subduction-accretion complexes. Gondwana Res. 2019, 74, 7-30. [CrossRef]

83. Starzec, K.; Malata, E.; Wronka, A.; Malina, L. Mélanges and broken formations at the boundary zone of the Magura and Silesian nappes (Gorlice area, Polish Outer Carpathians)_A result of sedimentary and tectonic processes. Geol. Q. 2015, 59, 169-178. [CrossRef]

84. Vannucchi, P.; Maltman, A.; Bettelli, G.; Clennell, B. On the nature of scaly fabric and scaly clay. J. Struct. Geol. 2003, 25, 673-688. [CrossRef]

85. Golonka, J.; Pietsch, K.; Marzec, P.; Stefaniuk, M.; Waskowska, A.; Cieszkowski, M. Tectonics of the western part of the Polish Outer Carpathians. Geodin. Acta 2009, 22, 127. [CrossRef]

86. Mikołajczak, M.; Barmuta, J.; Ponikowska, M.; Mazur, S.; Starzec, K. Depth-to-basement study for the western Polish Outer Carpathians from three-dimensional joint inversion of gravity and magnetic data. J. Geosci. 2021, 66, 15-36. [CrossRef]

87. Burbank, D.W.; Anderson, R.S. Tectonic Geomorphology; Wiley-Blackwell: Hoboken, NJ, USA, 2012. [CrossRef]

88. Wallace, R.E. Geometry and rates of change of fault-generated range fronts, north-central Nevada. J. Res. USA Geol. Surv. 1978, 6, 637-649.

89. Bull, W.B. Tectonic Geomorphology of Mountains: A New Approach to Paleoseismology; Blackwell Publishing Ltd.: Malden, MA, USA, 2007. [CrossRef]

90. Jankowski, L.S.; Margielewski, W.; Ratajczak-Szczerba, M.; Urban, J. Strukturalne i Litofacjalne Uwarunkowania Rozwoju Rzeźby Polskich Karpat Zewnętrznych. III Warsztaty Geomorfologii Strukturalnej: Beskid Niski, Beskid Sądecki, Babia Góra, Dukla, Piwniczna, Zawoja, 25-28 Września 2012 r; Instytut Ochrony Przyrody, Polska Akademia Nauk: Kraków, Poland, 2012.

91. Sanderson, D.J.; Marchini, W.R.D. Transpression. J. Struct. Geol. 1984, 6, 449-458. [CrossRef]

92. Christie-Blick, N.; Biddle, K.T. Deformation and Basin Formation along Strike-Slip Faults. Strike-Slip Deformation, Basin Formation, and Sedimentation; SEPM: Tulsa, OK, USA, 1985; pp. 1-34.

93. Sylvester, A.G. Strike-slip faults. Geol. Soc. Am. Bull. 1988, 100, 1666-1703. [CrossRef]

94. Storti, F.; Billi, A.; Salvini, F. Particle size distributions in natural carbonate fault rocks: Insights for non-self-similar cataclasis. Earth Planet. Sci. Lett. 2003, 206, 173-186. [CrossRef]

95. Segall, P.; Pollard, D.D. Faults Coyote Creek Fault trace Fold axis. J. Geophys. Res. 1980, 85, 4337-4350. [CrossRef]

96. Myers, R.; Aydin, A. The evolution of faults formed by shearing across joint zones in sandstone. J. Struct. Geol. 2004, 26, 947-966. [CrossRef]

97. Granier, T. Origin, damping, and pattern of development of faults in granite. Tectonics 1985, 4, 721-737. [CrossRef]

98. Martel, S.J. Formation of compound strike-slip fault zones, Mount Abbot quadrangle, California. J. Struct. Geol. 1990, 12, 869-882. [CrossRef]

99. De Joussineau, G.; Aydin, A. The evolution of the damage zone with fault growth in sandstone and its multiscale characteristics. J. Geophys. Res. Solid Earth 2007, 112, 1-19. [CrossRef]

100. Butler, R.W.H. The terminology of structures in thrust belts. J. Struct. Geol. 1982, 4, 239-245. [CrossRef]

101. Butler, R.W.H. Hangingwall strain: A function of duplex shape and footwall topography. Tectonophysics 1982, 88, 235-246. [CrossRef]

102. Charlesworth, H.A.K.; Johnston, S.T.; Gagnon, L.G. Evolution of the triangle zone in the Rocky Mountain Foothills near Coalspur, central Alberta. Can. J. Earth Sci. 1987, 24, 1668-1678. [CrossRef]

103. Baird, A.W.; Russell, A.J. Structural and stratigraphic perspectives on the uplift and erosional history of Djebel Cherichira and Oued Grigema, a segment of the Tunisian Atlas thrust front. Geol. Soc. Spec. Publ. 1999, 162, 127-142. [CrossRef]

104. Elliott, D.; Johnson, M.R.W. Structural evolution in the northern part of the Moine thrust belt, NW Scotland. Trans. R. Soc. Edinb. Earth Sci. 1980, 71, 69-96. [CrossRef]

105. Larrasoaña, J.C.; Parés, J.M.; Millán, H.; del Valle, J.; Pueyo, E.L. Paleomagnetic, structural, and stratigraphic constraints on transverse fault kinematics during basin inversion: The Pamplona Fault (Pyrenees, North Spain). Tectonics 2003, 22, 1-10. [CrossRef]

106. Searle, M.P.; Cooper, D.J.W.; Watts, K.F. Structure of the Jebel Sumeini-Jebel Ghawil area, Northern Oman. Geol. Soc. Spec. Publ. 1990, 49, 361-374. [CrossRef] 
107. Dahlstrom, C.D.A. Structural geology in the eastern margin of the Canadian Rocky Mountains. Bull. Can. Pet. Geol. 1970, 18, 332-406.

108. Zhang, J.; Ding, L.; Zhong, D.; Zhou, Y. Orogen-parallel extension in Himalaya: Is it the indicator of collapse or the product in process of compressive uplift? Chin. Sci. Bull. 2000, 45, 114-120. [CrossRef] 